\title{
Rūdolfs Cešeiko
}

\section{Maksimālais spēka treniņš krūts vēža pacientēm adjuvantas terapijas laikā}

Promocijas darba kopsavilkums zinātniskā doktora grāda "zinātnes doktors (Ph.D.)" iegūšanai

Nozare - veselības un sporta zinātnes Apakšnozare - sporta medicina un rehabilitologija 


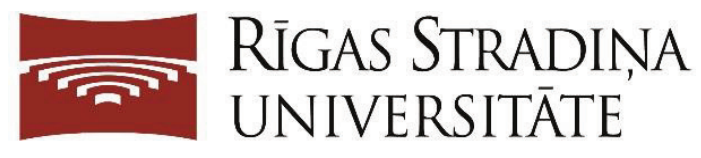

\author{
Rūdolfs Cešeiko \\ ORCID 0000-0002-2395-1306
}

Maksimālais spēka treniṇš krūts vēža pacientēm adjuvantas terapijas laikā

Promocijas darba kopsavilkums zinātniskā doktora grāda "zinātnes doktors (Ph.D.)" iegūšanai

Nozare - veselības un sporta zinātnes Apakšnozare - sporta medicīna un rehabilitologija 
Promocijas darbs izstrādāts Promocijas darbs izstrādāts Latvijas Onkologiijas centra Krūts ḳirurğijas nodạ̣ā, un Rīgas Stradiṇa universitātes Rehabilitācijas fakultātē, Latvijā

Promocijas darba vadītāji:

Dr. med. asociētā profesore Signe Tomsone,

Rīgas Stradiņa universitāte, Latvija

Dr. med. profesors Eivind Wang,

Norvēgijas Zinātnes un tehnoloğiju universitāte

Zinātniskie konsultanti:

Dr. med. profesors Jānis Eglītis, Latvijas Universitāte

Dr. med. profesors Aivars Vētra, Rīgas Stradiṇa universitāte, Latvija

Oficiālie recenzenti:

Dr. med. asociētā profesore Iveta Kudaba,

Rīgas Stradiṇa universitāte, Latvija

Ph.D. profesore Aija Kḷaviņa, Latvijas Sporta pedagoǵijas akadēmija

Ph.D. profesors Jan Hoff, Norvēǵijas Zinātnes un tehnoloǵiju universitāte

Promocijas darbs tiks aizstāvēts promocijas padomes "Veselības un sporta zinātnes" atklātā sēdē 2021. gada 11. augustā plkst. 14.00 gan Rīgas Stradiṇa universitātē, Dzirciema ielā 16, Hipokrāta auditorijā, gan attālināti Zoom tiešsaistes platformā

Ar promocijas darbu var iepazīties RSU bibliotēkā un RSU tīmekḷa vietnē: https://www.rsu.lv/promocijas darbi

Promocijas padomes sekretāre:

Dr. med. asociētā profesore Inese Gobina 


\section{Saturs}

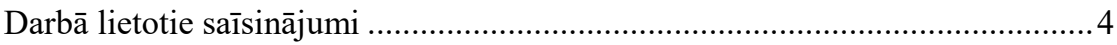

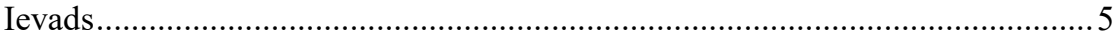

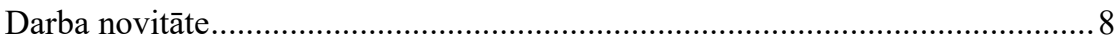

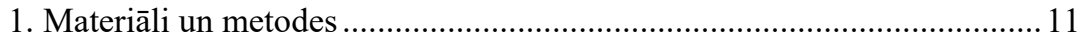

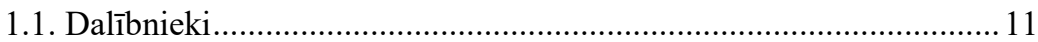

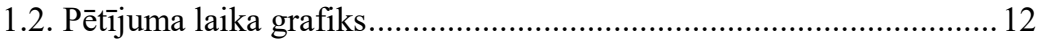

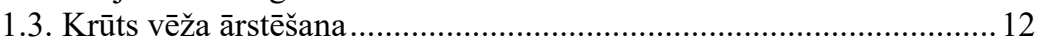

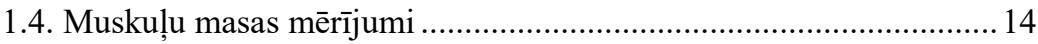

1.5. Maksimālā muskuḷu spēka noteikšana ................................................ 14

1.6. Fiziskā darba ekonomija .............................................................. 15

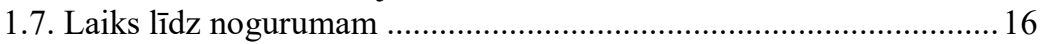

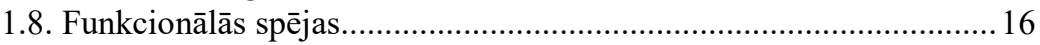

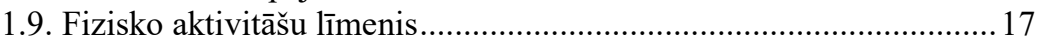

1.10. Dzīves kvalitāte, kas saistīta ar veselību .......................................... 17

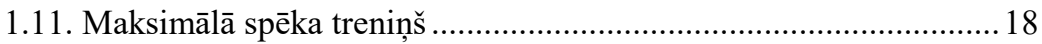

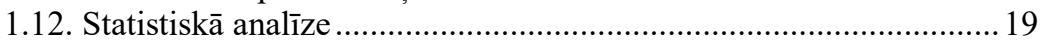

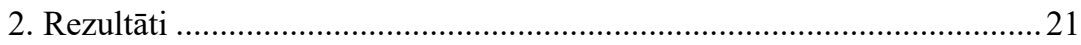

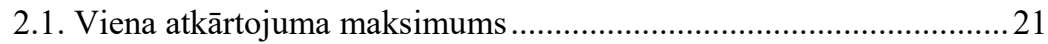

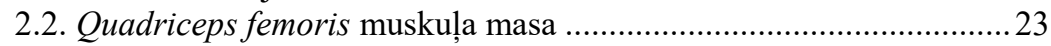

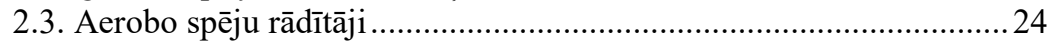

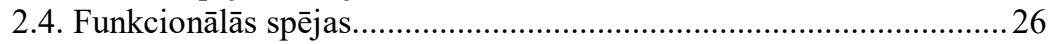

2.5. Dzīves kvalitāte, kas saistīta ar veselību ........................................... 31

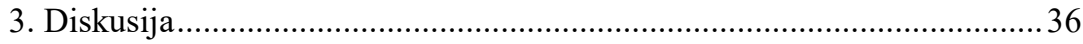

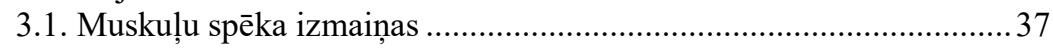

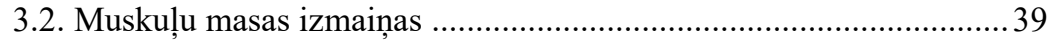

3.3. Funkcionālās spējas................................................................... 43

3.4. Maksimāla spēka trenini uzlabo fiziskā darba ekonomiju .................43

3.5. Augstas intensitātes spēka treniņu programmas tolerance ................ 46

3.6. Dzīves kvalitāte, kas saistīta ar veselību ........................................ 46

3.7. Pètījuma priekšrocības un ierobežojumi ........................................ 49

3.8. Klīniskā nozīme onkologijas pacientu rehabilitācijāa....................... 50

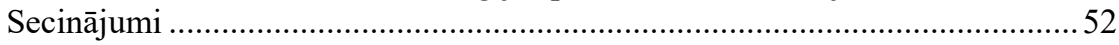

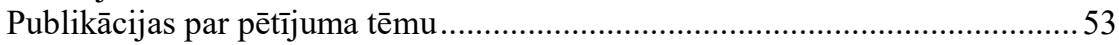

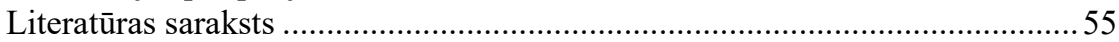

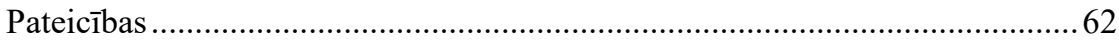




\section{Darbā lietotie saīsinājumi}

KV

DzK

EORTC

QoL

MST

1AM

Mqf

6MWD

RFD

PVO

CRF

KMB

DEXA

$\mathrm{VO}_{2 \text { maks }}$

ACSM

HOPS

PAS

IPAQ
Krūts vēzis

Dzīves kvalitāte, kas saistīta ar veselību

Eiropas Vēža izpētes un ārstēšanas organizācija

Vispārējais veselības stāvoklis

Maksimālā spēka treniņš

Viena atkārtojuma maksimums

Quadriceps femoris muskuḷa masa

6 minūšu iešanas testā noietā distance

Spēka attīstības ātrums

Pasaules Veselības organizācija

Ar vēzi saistītais nogurums

Kaulu minerālvielu blīvums

Osteodensitometrija

Maksimālā skābekḷa uzṇemšana

Amerikas Sporta medicīnas koledža

Hroniska obstruktīva plaušu slimība

Perifēro artēriju slimība

Starptautiskā aptauja par fizisko aktivitāti 


\section{Ievads}

Krūts vēzis (KV) ir visbiežāk diagnosticētais audzēja tips sievietēm vairāk nekā 2 miljonu jaunu saslimšanas gadījumu un vairāk nekā 600000 nāves gadījumu gadā (Bray et al., 2018), un tā sastopamība pasaulē nepārtraukti pieaug. KV pacientes piedzìvo sarežḡìtas veselības un psihosociālas problēmas. Fizisko aktivitāšu apjoma krituma dēl KV un pretvēža ārstēšanās process var samazināt muskuḷu masu un pasliktināt muskuḷu spēka attīstības rādītājus. Agrāk pacientiem, kuriem tika diagnosticēts vēzis, rekomendēja taupīt enerǵiju un izvairīties no aktīvas slodzes pēc diagnozes noteikšanas, bet šīs pieṇēmums pēdējo 20 gadu laikā ir ievērojami mainījies, jo fizisko aktivitāšu intervences onkologijāā ir ieguvušas respektējamu atzinību. Spēka treniņa mērḳis ir regulāru epizožu veidā stimulēt neiromuskulāro sistēmu, savukārt palielināts muskuḷu spēks var veicināt personas iesaisti ikdienas aktivitātēs, tādējādi uzlabojot dzīves kvalitāti, kas saistīta ar veselību (DzK). Tomēr vēl nav zināma optimāla spēka treniņa metodika (intensitāte, biežums, apjoms) onkoloǵisko pacientu ārstēšanās procesā, kas pretvēža ārstēšanas laikā kombinācijā ar noteiktu ārstēšanās plānu paaugstinātu maksimālo muskuḷu spēku.

Christensen et al. (Christensen et al., 2014) pētīja pirmreizēji apstiprinātus (krūts, kuṇǵa, kolorektāla, plaušu un aizkuṇǵa dziedzera) vēža pacientus un secināja, ka šiem pacientiem ir par $0,9 \mathrm{~kg}$ mazāka muskuḷu masa, salīdzinot ar veseliem kontroles grupas indivīdiem pat pirms pretvēža terapijas uzsākšanas. Turklāt adjuvantas ķīmijterapijas laikā KV pacientes zaudēja 1,3 kg muskuḷu masas un turpināja zaudēt muskuļu masu pēc terapijas pabeigšanas. Tika konstatēts, ka KV pacientēm muskuḷu spēks pēc primārās terapijas pabeigšanas bija samazinājies par 20-30 \%, salīdzinot ar veseliem cilvēkiem populācijā. Svarīgi uzsvērt, ka vairākums fizisko aktivitāšu pētījumu KV pacientēm kombinē aerobās izturības treniņu programmas un spēka treniņus, kā arī dažādas relaksācijas terapijas, tādējādi sarežǵījot specifisko treniņu veidu 
ietekmes novērtēšanu. Onkologijāa trūkst skaidri definētu klīnisko pētījumu KV pacientēm, kas ietvertu augstākas intensitātes spēka treniņus, turklāt apstākḷıs, kad intervence notiek adjuvantas ḳimijiterapijas laikā.

Klīniskajos spēka treniņa pētījumos onkologijā ievērojami atšķiras treniņos izmantotā intensitāte, sākot no 25 līdz 80 \% no viena atkārtojuma maksimuma (1 AM), lai gan ir dokumentēts, ka augstāka treniņu intensitāte rezultējas ar lielāku spēka pieaugumu gados jauniem un veseliem cilvēkiem (Campos et al., 2002). Turklāt lielāks muskuḷu spēka pieaugums ir dokumentēts, izmantojot pakāpeniski progresējošu treniņu intensitāti onkoloǵiskajiem pacientiem, tomēr iespējams, ka pacientiem ir novērojami fizisko spēju uzlabojumi, izmantojot zemu treniņu intensitāti (Fairman et al., 2017). Klīniskajos pētījumos, kuru ietvaros onkologiskajiem pacientiem tika veikta spēka treniņu intervence, secināts, ka treniņu programmas ir labi panesamas, tās ir drošas, izpildāmas un to rezultātā uzlabojas pacientu muskuḷu spēks, kas paaugstina fiziskās spējas un uzlabo DzK (Segal et al., 2003), (De Backer et al., 2007), (Battaglini et al., 2014). Konstatēts, ka treniņu intensitāte spēka treniņos ir galvenais faktors, kas palielina maksimālo muskuḷu spēku un ar spēku saistītos rādītājus. Līdz ar to ir būtiski veidot labi strukturētas treniņu programmas, nošķirot aerobo treniņu no spēka treniņa, kur skaidri ir aprakstīta treniņa metodolog̣ija (intensitāte, apjoms, biežums), lai rezultāti būtu vieglāk salīdzināmi ar citiem pētîjumiem par fiziskajām aktivitātēm KV pacientēm. Līdz ar to ir nepieciešamas precīzi definētas un aprakstītas augstākas intensitātes spēka treniņu metodes, lai veicinātu fizioloǵisko procesu lielāku adaptāciju, potenciāli veiksmīgāk izturētu ieplānoto ārstēšanas kursu, ātrāk atgūtu fiziskās spējas un atjaunotu sev vēlamās sociālās lomas. 


\section{Pētījuma mērḳis}

Pētnieciskā darba mērḳis bija izpētît maksimālā spēka treniņa (MST) ietekmi uz viena atkārtojuma maksimumu (1 $\mathrm{AM})$, funkcionālajām spējām, fiziskā darba ekonomiju, muskuļu masu un dz̄̄ves kvalitāti, kas saistīta ar veselību (DzK) sievietēm ar krūts vēzi I-III stadijā, kurām tiek veikta adjuvanta kīmijterapija.

\section{Pētījuma mērḳa sasniegšanai tika izvirz̄iti sekojoši uzdevumi:}

- Izpētīt MST ietekmi uz apakšējo ekstremitāšu maksimālo muskuḷu spēku, izmantojot trenažieri spiešanai ar kājām, lietojot augstāku intensitāti 90 \% no 1AM, uzsvaru liekot uz maksimālu spēka mobilizāciju koncentriskajā kustības fāzē.

- $\quad$ Noskaidrot, vai MST ārstēšanas laikā ietekmē KV pacienšu Quadriceps femoris muskulu masu (Mqf).

- Izpētīt, vai MST ietekmē aerobās spējas.

- Izpētīt MST ietekmi uz funkcionālajām spējām, izmantojot standartizētus funkcionālos testus pirms intervences un pēc tās.

- Noteikt, vai MST ietekmē DzK, izmantojot Eiropas Vēža izpētes un ārstēšanas organizācijas (EORTC) pamata anketu (C30) un papildu moduli (BR23) pirms intervences un pēc tās.

\section{Pētījuma hipotēze}

Divpadsmit nedēḷ MST ar uzsvaru uz maksimālu spēka mobilizāciju kustības koncentriskā fāzē palielinās maksimālo muskuḷu spēku apakšējām ekstremitātēm, tā rezultātā sekmējot funkcionālās spējas, fiziskā darba ekonomiju, DzK un saglabājot muskuḷu masu adjuvantas ķīmijterapijas laikā, bet 
maksimālais muskuḷu spēks, funkcionālās spējas, fiziskā darba ekonomija, muskuḷu masa un DzK samazinās pēc adjuvantas ķīmijterapijas, ja netiek veikti spēka treninini.

\section{Darba novitāte}

Ārstēšanas process un mērķtiecīgu fizisko aktivitāšu trūkums pēc KV diagnozes vecina muskuḷu spēka samazināšanos, un tā rezultātā daudzām KV pacientēm ir īpaši zemas fiziskās spējas. Kaut arī ir respektējams skaits pētījumu par neiromuskulāro un funkcionālo adaptāciju spēka treniņu rezultātā, ir pārsteidzoši maz pētīta spēka treniņu ietekme uz KV ārstēšanas agrīno, kritisko posmu. Turklāt dažos iepriekšējos pētījumos, kuros veikti klīniskie spēka treniņi (Courneya et al., 2007b), (Battaglini et al., 2007), (Campbell et al., 2012), (Cheema et al., 2008), ir piemērota zema vai vidēja slodzes intensitāte $(<75$ \% 1AM). Pêtījumu rezultāti parāda būtisku muskuļu spēka samazināšanos apakšèjām ekstremitātēm pēc kịmijterapijas KV pacientēm (Schwartz and Winters-Stone, 2009), savukārt ne visos pētījumos tiek konstatēts muskuḷu spēka pieaugums, izmantojot zemāku intensitāti (< 75 \% 1AM) (Buffart et al., 2020; Cornette et al., 2016; Courneya et al., 2007a; Mijwel et al., 2018b; Schmidt et al., 2015; Travier et al., 2015; van Waart et al., 2015a).

Jānorāda, ka klīnisko pētījumu laikā aerobās izturības intervences ir bijušas visbiežākās intervences izvēles onkologiiskajiem pacientiem. Tādējādi ir atzīstami tikai daži pētījumi, kuru ietvaros veikti spēka treniņi, tomēr tie palielina pretrun̄̄go pierādījumu apjomu, norādot, ka novērojumu nekonsekvence var būt saistīta ar ķīmijterapijas veidu, ilgumu un kumulatīvo devu. Visbiežāk spēka treniņu intervences onkologijāa ietver tradicionālo spēka treniņu metodiku, kurā tiek izmantota zema vai vidēja treniṇu intensitāte $25-75 \%$ 1AM, veicot 13 vingrojumu sērijas ar 8-12 reižu atkārtojumiem, ar lēnu kustības ātrumu 
koncentriskajā fāzē, intervencei ilgstot no 4 nedẹlāam līdz 12 mēnešiem, parasti uzsākot treniṇu procesu pēc ārstēšanas pabeigšanas un iesaistot pacientus, kuri sasnieguši piecu gadu izdzīvotības daḷu (Buffart et al., 2020; Cornette et al., 2016; Mijwel et al., 2018b; Schmidt et al., 2015).

Līdz šim nav zināmi pētījumi, kuros izmantota augstākas intensitātes spēka treniņu metodika KV pacientēm un jo īpaši adjuvantas ķīmijterapijas laikā. Tādēḷ šajā pētîjumā tika izmantots MST, lai sekmētu neiromuskulārās adaptācijas, izmantojot nelielu skaitu atkārtojumu $(\leq 5)$ ar lielāku intensitāti ( 85-95 \% 1AM) un atpūtas periodus, kas ilgāki par $\geq 3$ minūtēm starp sērijām, 2 reizes nedēḷā, 12 nedēḷas, treniņus veicot adjuvantas ķīmijterapijas laikā. Svarīgi, ka trenažieris spiešanai ar kājām tika izvēlēts kā muskuḷu spēka testēšanas un treniņu procesa pamatiekārta ne tikai tāpēc, ka tā precīzi atspoguḷo funkcionālās spējas ikdienas uzdevumu veikšanas laikā (Unhjem et al., 2017), bet arī tāpēc, ka tā nodarbina vairākas apakšējo ekstremitāšu muskuḷu grupas.

Ṇemot vērā ārstēšanas blaknes adjuvantas terapijas agrīnajā posmā, jo īpaši saistībā ar antraciklīnu ietekmi un vāju funkcionālo stāvokli tūlīt pēc ārstēšanas, nav zināms, vai augstākas intensitātes spēka treniṇi varētu nodrošināt līdzīgu neiromuskulāro un funkcionālo ietekmi, kā tas novērots citās pacientu grupās, un vai to ir iespējams veikt KV pacientēm neilgi pēc operācijas.

Svarīgi norādīt, ka Latvijas Republikā medicīniskā rehabilitācija onkologiskajiem pacientiem ir ierobežota un ne visas efektīvas spēka treniņu metodes ir atzītas. Kā secināts Latvijas Republikas Valsts kontroles revīzijas ziṇojumā "Vai medicīniskā rehabilitācija tiek sniegta pacientiem, kam tā ir vajadzīga, un pareizajā laikā?”, onkologisko pacientu rehabilitācija ir nepietiekama un jau ilgstoši tā nav bijusi prioritāte (L.R.V.K, 2018). Ārstēšanās laikā ir prognozējama būtiska fizisko spēju un funkcionalitātes samazināšanās, (Klassen et al., 2017). Samazinoties fiziskajām spējām, vairumam pacienšu būs 
samazināta līdzdalība ikdienas aktivitātēs un būtiski ietekmēta dz̄ives kvalitāte, kas saistita ar veselību (Møller et al., 2020).

Tāpēc, ņemot vērā pieaugošo KV pacienšu un pacientu skaitu, kas sasnieguši piecu gadu dzīvildzi, promocijas darbs apkopo svarīgas zināšanas par spēka treniņu noz̄imi KV pacientēm. Šì informācija var noderēt, lai veicinātu dialogu starp veselības aprūpes speciālistiem un veselības politikas veidotājiem, lai veidotu inovatīvas, izmaksu un laika ziṇā efektīvas stratēgijas, lai izstrādātu piemērotas rehabilitācijas programmas onkologijāa un papildus sekmētu šì jaunā, daudzsološā pētniecības virziena attīstību.

\section{Personīgais ieguldījums}

Izstrādājot šo pētījumu, tika veiktas visas pirmreizējās un atkārtotās pacientu novērtēšanas (kopā 110 procedūras), uzraudzītas un īstenotas 1248 treniņu nodarbības. Autors ir apkopojis zinātniskos datus, interpretējis datus, veicis statistisko analīzi un uzrakstījis šo darbu.

\section{Promocijas darba struktūra un apjoms}

Doktora darbs sarakstīts angḷu valodā. Darbu veido četras nodaḷas literatūras apskats, metodika, rezultāti, diskusijas - un nobeigums. Darbs sastāv no 93 lappusēm, ieskaitot 6 tabulas, 8 attēlus. Literatūras sarakstā ir 221 avots. 


\section{Materiāli un metodes}

\subsection{Dalībnieki}

Pētījumā tika iekḷautas 57 pacientes ar pirmreizēji diagnosticētu I-III stadijas KV, kurām bija noteikta sistēmiskā terapija un staru terapija, ārstēšanas procesam notiekot Latvijas Onkoloǵijas centrā. Iekḷaušanas kritēriji: sievietes vecumā no 18 līdz 63 gadiem ar pirmreizēji (< 3 nedēḷas) diagnosticētu I-III stadijas KV, kam noteikta ārstēšana, veicot krūts dziedzeri saglabājošu operāciju vai mastektomiju un adjuvantu terapiju (staru terapiju un/vai adjuvantu ķīmijterapiju). Izslēgšanas kritēriji: sirds slimības (koronārā sirds slimība, stenokardija, sirds mazspēja, mirdzaritmija, miokarda infarkts, primārā arteriālā hipertensija), cukura diabēts (insulinējams, neinsulinējams), apakšējo ekstremitāšu muskuloskeletālie traucējumi (osteoartrīts, sāpes sakroileokālajās locītavās, bursīts ceḷa locītavā, tendinīts, koksartroze, gonartroze, potītes locītavas traumas, menisku bojājumi) un citi traucējumi, kas liedza līdzdalību testēšanas procedūrās vai maksimālā spēka treniṇos (MST).

Pacientes tika randomizētas MST grupā vai kontroles grupā. Pirms randomizācijas pacientes tika stratificētas 3 blokos, pamatojoties uz diagnosticēto KV, attiecīgi I stadiju, II stadiju un III stadiju; pēc tam, izmantojot bloku randomizāciju, pacientes katrā blokā tika randomizētas MST grupā vai kontroles grupā. Neilgi pēc iekḷaušanas un pirms randomizācijas 2 pacientes (vidējais vecums 52 gadi) izstājās no turpmākas līdzdalības pētījumā ğimenes vai darba apstākḷu dēḷ. Tādēl tika randomizētas 55 pacientes (MST grupa; N=27), (kontroles grupa; $\mathrm{N}=28$ ), kuras noslēdza pētījumu (1.1. tabula). Pētījums tika veikts saskaņā ar Helsinku deklarāciju. Tika saņemts apstiprinājums no Rīgas Stradiṇa universitātes ētikas komitejas un Rīgas Austrumu klīniskās universitātes slimnīcas stacionāra "Latvijas Onkologijas centrs" zinātnes daḷas atḷauja par pētījuma veikšanu. 


\subsection{Pētījuma laika grafiks}

Pētījumā iekḷautās pacientes sākumā veica standartizētu 1,5 stundu ilgu testēšanas procedūru 2-3 nedēlas pēc operācijas. Svarīgi bija uzsākt MST, cik drīz vien iespējams, pēc operācijas. Tas tika uzsākts, saņemot kirurga apstiprinājumu, ka operētās vietas dz̄ī̌anas process norit bez komplikācijām. Pēc tā apstiprināšanas pacientes tika randomizētas 1:1 standarta terapija ar 12 nedēḷ ilga pārraudzīta MST vai bez tā. Pacientes, kas tika iekḷautas MST grupā, sāka treniņus 1-2 dienas pēc pirmreizējās testēšanas un 1 nedēḷ pirms adjuvantas ķīmijterapijas uzsākšanas, līdz ar to visas pacientes pakāpeniski trenējās adjuvantas ķīmijterapijas laikā. Pēc 12 nedẹ̄̂ām tika atkārtota 1,5 stundu ilga testēšanas procedūra abām pētījuma grupām. Testēšanas procedūra sākās ar Quadriceps femoris muskuḷa masas (Mqf) mērījumiem, pēc tam pacientēm tika veikti vairāki funkcionālo spēju testi. Pēc īsa pārtraukuma tika novērtēts dinamiskais maksimālais apakšējo ekstremitāšu muskuļu spēks un noteikts (1AM), pēc tam pacientes turpināja ar submaksimālo slodzes testu, kura laikā izmērīja fiziskā darba ekonomiju un laiku līdz nogurumam inkrementāla slodzes testa laikā. Visbeidzot pacientes aizpildīja DzK anketas.

\subsection{Krūts vēža ārstēšana}

Visas iekḷautās pacientes tika ārstētas saskaṇā ar Eiropas Medicīniskās onkologijas biedrības (ESMO) un Amerikas Nacionālā visaptverošā vēža tīkla (NCCN) vadlīnijām. Ķirurǵiskā ārstēšana ietvēra: krūts saglabājošas operācijas (ar onkoplastisko tehniku vai bez tās) ar sargmezgla biopsiju vai paduses limfadenektomiju; krūts amputācijas ar sargmezgla biopsiju, mastektomijas. Pēc operācijas pacientēm bija noteikta adjuvanta pretvēža terapija, saṇemot ķīmijterapiju un/vai staru terapiju, un/vai mērḳterapiju (Trastuzumab), un/vai endokrīno terapiju. Ķ̄imijterapija sastāvēja no 4-8 doksorubicīna (50-60 mg • 
m- 2) vai epirubicīna [60-90 mg · m-2] un ciklofosfamīda (600 mg m-2) cikliem, ievadot medikamentus reizi trijās nedēlāâs. Pēc antraciklīna terapijas pabeigšanas dažām pacientēm bija noteikti arī 4 paklitaksela $(135-175 \mathrm{mg} \cdot \mathrm{m}-2)$ vai docetaksela (75-100 mg · m-2) cikli, ievadot reizi trijās nedēḷās. Pacientes ar HER2 pozitīvu audzēju tika ārstētas ar 18 trastuzumaba cikliem (600 mg · m- ), ko ievadīja reizi trijās nedẹ̄̂̄âs pēc ķīmijterapijas kursu noslēgšanas. Dažas pacientes pēc ķīmijterapijas pabeigšanas saṇēma hormonterapiju (selektīvu estrogēnu receptoru modulatoru - tamoksifēnu un/vai aromatāžu inhibitorus, piemēram, anastrozolu) un bifosfonātus (1.1. tabula).

1.1. tabula

\section{Antropometriskie parametri un ārstēšana}

\begin{tabular}{|c|c|c|c|}
\hline & $\begin{array}{l}\text { MST grupa } \\
(n=27)\end{array}$ & $\begin{array}{l}\text { Kontroles grupa } \\
(\mathrm{n}=28)\end{array}$ & $\begin{array}{l}\text { P- } \\
\text { vērtība }\end{array}$ \\
\hline Vecums (gadi) & $48 \pm 7$ & $49 \pm 8$ & 0,69 \\
\hline Svars $(\mathrm{kg})$ & $77,0 \pm 15,2$ & $72,3 \pm 17,4$ & 0,29 \\
\hline Augums (cm) & $170 \pm 6$ & $167 \pm 6$ & 0,07 \\
\hline $\begin{array}{l}\text { Krūts vēža stadija, TNM } \\
\text { klasifikācija(\%) }\end{array}$ & & & 0,57 \\
\hline IA, IB & $9(33)$ & $13(46)$ & \\
\hline IIA, IIB & $12(44)$ & $9(32)$ & \\
\hline IIIA, IIIB, IIIC & $6(23)$ & $6(22)$ & \\
\hline Ķirurgisiskā ārstēšana (\%) & & & 0,37 \\
\hline Krūts sektorālā rezekcija & $16(59)$ & $22(78)$ & \\
\hline $\bar{A} d u$ saglabājoša mastektomija & $5(19)$ & $4(14)$ & \\
\hline Krūts amputācija & $4(15)$ & $1(4)$ & \\
\hline Mastektomija pēc Madena & $2(7)$ & $1(4)$ & \\
\hline \multicolumn{4}{|l|}{ Adjuvantā terapija (\%) } \\
\hline Staru terapija & $23(85)$ & $26(92)$ & 0,42 \\
\hline Ķīmijterapija: & & & \\
\hline Antraciklīnu grupas preparāti & $25(93)$ & $24(86)$ & 0,70 \\
\hline Ciklofosfamīds & $14(52)$ & $17(61)$ & 0,51 \\
\hline Taksānu grupas preparāti & $16(59)$ & $16(57)$ & 0,88 \\
\hline Trastuzumabs & $3(11)$ & $3(10)$ & 0,99 \\
\hline Endokrīnā terapija & $15(44)$ & $15(46)$ & 0,75 \\
\hline
\end{tabular}

Nepārtraukti main̄̄gie ir prezentēti kā vidējā vērtīibā \pm standartnovirze un kategoriskie dati ir prezentēti kā skaits (n), (\%). 


\subsection{Muskuḷu masas mērījumi}

Quadriceps femoris (Mqf) masa tika noteikta: kreisā augšstilba tilpums (V) tika aprēḳināts, izmantojot šādu vienādojumu (Layec, Venturelli et al. 2014): $\mathrm{V}=\mathrm{L} \cdot 12 \pi^{-1} \cdot\left(\mathrm{C}^{2}+\mathrm{C} 2^{2}+\mathrm{C} 3^{2}\right)-(\mathrm{S}-0.4) \cdot 2^{-1} \cdot \mathrm{L} \cdot(\mathrm{C} 1+\mathrm{C} 2+\mathrm{C} 3) \cdot 3^{-1}$

Izmantojot standarta mērlenti, augšstilba garumu (L) mērīja no augšstilba kaula laterālā virspaugura līdz lielajam grozītājam. Augšstilba apkārtmērs tika mērīts viduspunktā $(\mathrm{C} 1)$ un $10 \mathrm{~cm}$ distāli $(\mathrm{C} 2)$, un $10 \mathrm{~cm}$ proksimāli $(\mathrm{C} 3)$ no viduspunkta. Turklāt viduspunktā tika veikti trīs ādas krokas mērījumi (S): mediāli, priekšpuses un laterāli, un pēc tam tika aprēķināts vidējais aritmētiskais visam augšstilbam, izmantojot ādas krokas kaliperu (SH5020, Saehan Corporation, MD, Dienvidkoreja). Quadriceps femoris muskuḷa masa (Mqf) tika aprēḳināta kā Mqf =0,307 • V + 0,353 kg (Radegran, Blomstrand et al., 1999).

\subsection{Maksimālā muskuḷu spēka noteikšana}

Pirms visiem spēka mērījumiem tika veikta zemas intensitātes iesildīšanās, kas sastāvēja no 2-3 sērijām, kurās tika izpildīti 6-8 atkārtojumi. Maksimālais dinamiskais muskuḷu spēks apakšējām ekstremitātēm tika mērīts kā 1AM standartizētā kustībā, izmantojot trenažieri spiešanai ar kājām (Cybex Eagle 1040, ASV). Sākot ar ceḷa locītavām gandrīz $180^{\circ}$ leṇḳ̄i, pacientes lēni ceḷgalus salieca $90^{\circ}$ leṇkī un pēc tam koncentriski ar maksimālu spēka mobilizāciju veica kustību atpakaḷ sākotnējā pozīijāa (1.1. attēls). Slodze tika palielināta par 2,5-7,5 kg, līdz pacientes vairs nespēja veikt spiešanas kustību. 1AM tika definēts kā lielākais paceltais svars, un parasti tas tika iegūts 3- 6 mēǵinājumos. Starp katru spiešanas kustību tika ievēroti vismaz 3 minūšu atpūtas periodi. 

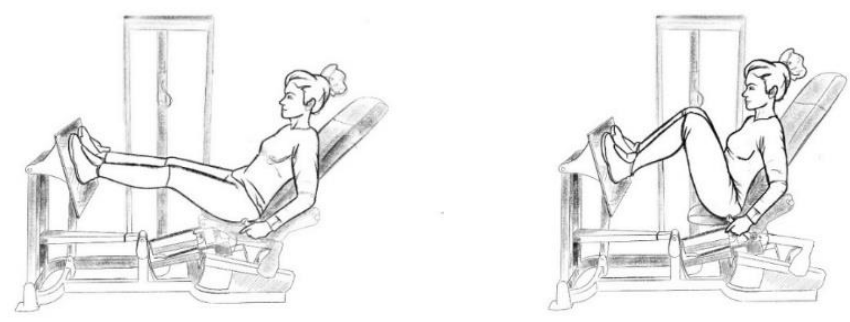

\section{1. attēls. Viena atkārtojuma maksimuma noteikšana un trenēšana, izmantojot trenažieri spiešanai ar kājām.}

\subsection{Fiziskā darba ekonomija}

Fiziskā darba ekonomija tika novērtēta submaksimālas slodzes laikā, staigājot uz slīdošā celiṇa trenažiera. Pirms testa pacientes tika iepazīstinātas ar staigāšanu pa slīdceliņu. Pēc 5 minūšu iesildīšanās pašas izvēlētā ātrumā pacientes turpināja ar 5 minūšu submaksimālu fiziskā darba ekonomijas testu, ko veica pa motorizētu slīdceliņu (Spirit CT 100, Jonesboro, ASV) ar 5 \% slīpumu. Ātrums tika aprēḳināts, lai iegūtu 40 vatu darba slodzi katrai pacientei, izmantojot vienādojumu (Høydal, Helgerud et al. 2007):

$\bar{A} \operatorname{trums}\left(\mathrm{Km} \cdot \mathrm{h}^{-1}\right)=\frac{40 \mathrm{vati}}{\left[\mathrm{m}_{\mathrm{b}} \cdot \mathrm{N}\right] \cdot \sin \theta} \cdot 3.6$

kur $m_{b}$ ir konkrētās pacientes ķermeņa masa, $\mathrm{N}$ ir N̦ūtons, kas pārveidots kilogramos, un $\theta$ ir slīdošā celiņa $5 \%$ slīpums. Tādējādi visas pacientes ar atšķirīgu ķermeņa masu staigāja pa slīdceliņu ar darba slodzi, kas atbilst 40 vatiem, kas nozīmē katrai atšķirīgu iešanas ātrumu. Fiziskā darba ekonomija tika definēta kā vidējais aritmētiskais sirdsdarbības frekvencei, izmantojot sirds ritma mērītāju (Polar Electro FT7, Kempele, Somija) pēdējā minūtē no 5 minūtēm 40 vatu darba slodē. Turklāt pacientēm tika lūgts norādīt slodzes 
intensitātes pašnovērtējumu par sajusto piepūli (Borga skala) (6-20), lai novērtētu sajusto piepūli piektās minūtes beigās.

\subsection{Laiks līdz nogurumam}

Pēc fiziskā darba ekonomijas testa pacientes uzreiz turpināja ar inkrementālu slodzes testu, lai izmērītu laiku (s) līdz brīvprātīgam nogurumam. Ātrums tika turēts nemain̄̄gs 3,8 vai $4,8 \mathrm{~km} / \mathrm{h}^{-1}$ atkarībā no pacientes pašsajūtas, un slīpums tika palielināts katru minūti par $2 \%$. Ja paciente spēja turpināt slodzi pēc $12 \%$ slīpuma sasniegšanas, ātrums tika palielināts par $0,5 \mathrm{~km} / \mathrm{h}^{-1}$ minūtē, līdz paciente atzīst nogurumu (Wolthuis, Froelicher et al., 1977). Tūlīt pēc noguruma testa tika reǵistrēta sirdsdarbības frekvence un noteikta subjektīva slodzes intensitāte (Borga skala). Pirms testa pacientēm tika skaidrots, ka iespējams pēc subjektīvām sajūtām sasniegt lielu slodzi (17-19 pēc Borga skalas), kā arī pirms testa tika aprēḳināta maksimālā pieḷaujamā sirdsdarbības frekvence ( 90 \% no maksimālās).

\subsection{Funkcionālās spējas}

Lai noteiktu funkcionālās spējas, tika izmantoti trīs standartizēti funkcionālie testi. Pirmkārt, tika mērīta 6 minūšu laikā noietā distance (m), 6 minūšu iešanas tests (6MWD). Pacientes tika instruētas iet turp un atpakal un ap diviem konusiem, kas atradās > 20 metru attālumā, ar attāluma intervāla marķējumu ik pēc 3-5 metriem, lai noietu garāko iespējamo attālumu 6 minūtēs (Dobson, Hinman et al., 2013).

Otrajā testā (30 sekunžu piecelšanās un apsēšanās tests) tika noteiktas reizes, cik persona spēj piecelties un apsēsties uz krēsla 30 sekundēs. Sākot no sēdus stāvokḷa ar sakrustotām rokām uz pleciem, pacientēm tika uzdots piecelties 
no $44 \mathrm{~cm}$ augsta krēsla un apsēsties tik reižu, cik vien iespējams 30 sekundēs (Guralnik, Simonsick et al., 1994).

Treškārt, pakāpienu tests, novērtējot spēju kāpt pa kāpnēm, - cik daudz laika nepieciešams, lai pēc iespējas ātrāk uzkāptu un nokāptu pa desmit $18 \mathrm{~cm}$ augstiem pakāpieniem, neizmantojot margu atbalstu; tika reǵistrēts labākais rezultāts no diviem mēgeinājumiem (Fiatarone, O'Neill et al., 1994).

\subsection{Fizisko aktivitāšu līmenis}

Neilgi pirms plānotās operācijas (parasti 1-2 dienas) pacientēm tika jautāts, vai viņas katru nedēḷ nodarbojas ar fiziskām aktivitātēm, lūdzot aizpildīt "Starptautiskās aptaujas par fizisko aktivitāti” (IPAQ - SF) īso formu. IPAQ mērḳis bija noteikt šajā pētījumā iekḷauto pacienšu fiziskās aktivitātes līmeni. Iepriekš Latvijas Republikā A. Kaupužs (Kaupužs, 2011) izmantoja IPAQ savā disertācijā, kur tā tika apstiprināta un atkārtoti pārbaudīta. IPAQ aprēķina vidējo nedēḷas fiziskās aktivitātes līmeni, aplēšot uzdevuma metabolisko ekvivalenta (ME) punktu skaitu un kopējo minūšu skaitu nedēḷā, kas pavadīts zemas, vidējas un augstas intensitātes aktivitātēs (attiecīgi 3,3, 4,0 un 8,0 ME minūtes/nedēḷā). IPAQ iepriekš ir pārbaudīta un dokumentēta, atzīstot to par derīgu un uzticamu aptauju (Craig, Marshall et al., 2003). Turklāt pacientēm papildus tika jautāts, vai pēdējos 6 mēnešos pirms diagnozes noteikšanas viṇas regulāri ( $\geq 2 \times$ nedẹ̄̂ā) veica mērḳtiecīgus spēka treniņus.

\subsection{Dzīves kvalitāte, kas saistīta ar veselību}

DzK tika noteikta, izmantojot Eiropas Vēža izpētes un ārstēšanas organizācijas "Dz̄ives kvalitātes anketu" (EORTC QLQ-C30), kas sastāv no 30 jautājumu blokiem (3.0. versija), un papildu krūts vēža moduli (QLQ-BR23) (Aaronson, Ahmedzai et al., 1993). EORTC QLQ-C30 un QLQ-BR23 ir 
apvienota sistēma klīniskajos pētījumos iesaistīto onkoloǵisko pacientu DzK novērtēšanai. QLQ-C30 sastāv no vairāku pozīciju skalām un vienas pozīcijas novērtējumiem. Tajā ir 5 funkcionālās skalas (fiziskā funkcija, lomu funkcija, emocionālā funkcija, kognitīvā funkcija, sociālā funkcija), 3 simptomu skalas, vispārējā veselības stāvokḷa/QoL skala un 6 atsevišķas pozīcijas. Būtiski norādīt, ka katrā no vairāku pozīciju skalām ir iekḷauta atšķirīga pozīciju kopa - neviena no pozīcijām nav ietverta vairāk kā vienā skalā. Turklāt QLQ-BR23 modulis sastāv no 23 jautājumiem, ar kuriem novērtē slimības simptomus, ārstēšanas blaknes (operācija, ķīmijterapija, staru terapija un hormonālā terapija), priekšstatu par ķermeņa izskatu, seksuālo funkciju un nākotnes perspektīvas (Aaronson, Ahmedzai et al., 1993). Visas skalas un vienas pozīcijas novērtējuma punkti ir no 0 līdz 100. Augsts rezultāts nozīmē augstāku atbildes līmeni. Tādējādi augsts funkcionālās skalas punktu skaits nozīmē augstu/veselīgu funkciju līmeni, augsts vispārējā veselības stāvokḷ/Q/QoL punktu skaits nozīmēe augstu QoL, bet augsts simptomu skalas/pozīcijas punktu skaits nozīmē augstu simptomatologiju/problēmas (Fayers, P., 2001).

\subsection{Maksimālā spēka treniṇ̌s}

MST grupa 12 nedēḷas apmeklēja divus pārraudzītus/klātienē organizētus treniņus nedēḷā. Treniņi tika realizēti Latvijas Onkoloğijas centra Krūts ķirurğijas nodaḷā, Rīgā, Latvijā. MST tika veikts, izmantojot trenažieri spiešanai ar kājām (kustības izpilde identiska 1AM testēšanas laikā). Pēc divām iesildīšanās sērijām (svars 50-60\% no 1AM) pacientes veica 4 sērijas ar 4 atkārtojumiem katrā sērijā ar intensitāti, kas atbilst 90 \% 1AM. Uzsvars tika likts uz lēnu kustību ekscentriskajā fāzē un maksimālu spēka mobilizāciju koncentriskajā kustības fāzē. Starp ekscentrisko un koncentriskās kontrakcijas fāzi tika ieturēta pauze $\sim 0,5 \mathrm{sek}$. Starp vingrojumu sērijām tika ieturētas vismaz 3 minūšu atpūtas pauzes. Ja paciente spēja veikt visas vingrojumu sērijas un 
ceturtajā sērijā spēja pacelt svaru piekto reizi, slodze tika palielināta par 2,5 kg. Pacientes piedalījās treniņos nelielās grupās pa 3-5 personām, un visi treniṇi tika uzraudzīti. Viena treniņa sesija ilga $\sim 20$ minūtes, un katru reizi pacientei, ierodoties uz treniṇu, tika jautāts, vai viņai MST dēḷ ir bijis diskomforts, sāpes vai citas nevēlamas blaknes MST laikā vai starp treniniem. Kontroles grupa 12 nedēlas divas reizes nedēḷa veica piecelšanos un apsēšanos no krēsla, veicot 3 sērijas ar 10 atkārtojumiem katrā sērijā. Šāda izvēle tiek pamatota, lai parādītu iespējamo spēka kritumu kontroles grupā, lai parādītu iespējamas sekas, kas notiek ar muskuḷu spēku un pārējiem mērītajiem parametriem KV pacientēm, saņemot ārstēšanos bez mērķtiecīga spēka treniņa (pašreizējā situācija valstī). Bieži pacienti fizisko aktivitāšu pētījumos nelabprāt vēlas būt kontroles grupā un ārpus pētījuma protokola meklē dažādas fizisko aktivitāšu iespējas, kas savukārt būtiski ietekmē pētîjuma datu precizitāti. Kontroles grupas pacientes reizi nedēḷā saņēma zvanu no pētījuma vadītāja, lai precizētu pašsajūtu un noteiktā uzdevuma izpildi. Visām pētījuma dalībniecēm tika uzsvērts nepalielināt fizisko aktivitāšu apjomu pētījuma laikā. Pēc pētījuma visas pacientes (MST grupa un kontroles grupa) saṇēma bezmaksas fizisko aktivitāšu ieteikumus, pamatojoties uz ACSM vadlīnijām (Campbell, Winters-Stone et al., 2019).

\subsection{Statistiskā analīze}

Statistiskā analīze tika veikta, izmantojot IBM SPSS programmu v.25 (IBM, USA) un Prism v.8.0 (GraphPad, USA). Atkarīgo pazīmju (kontroles, pētījuma) izmaiņu (pirms/pēc) novērtēšanai izmantoja atkārtotu mērījumu dispersiju analīzi (Repated measures mixed ANOVA). Neatkarīgo izlašu t-testu izmantoja divu izlašu vidējo vērtību atšķirības izvērtēšanai, bet atkarīgo izlašu

t- testu izmantoja kvantitatīvās pazīmes pirms/pēc novērtējumam. Spīrmena (Spearman, rs) korelācijas koefícienta analīze tika izmantota, lai analizētu sakarības starp kvantitatīvajām un rangu pazīmēm, piemēram, lai novērtētu 
korelāciju starp izmaiṇām pirms un pēc testa $1 \mathrm{AM}$ un pirms un pēc testa izmain̄ām fiziskā darba ekonomijā, laiks līdz nogurumam, QoL. Pīrsona hī kvadrāta (Pearson Chi square) vai Fišera precīzo (Fisher exact) testu izmantoja kategorisko datu analīzē atbilstoši to lietošanas nosacījumiem. Divpusēja p- vērtība, kas $<0,05$, tika uzskatìta par statistiski nozīmīgu. Koena d vērtība (Cohen's d) tika izmantota statistiskā efekta novērtēšanai, kas pēc ciešuma tika iedalīts četrās gradācijās: $0,1-0,2$ - mazs; $0,3-0,5$ - vidējs; $0,6-0,8$ - liels; $>0,9-$ loti liels. 


\section{Rezultāti}

Pētījuma procesu veiksmīgi noslēdz 55 no 57 sākotnēji iekḷautajām pacientēm (2.1. tabula). Divu pacienšu atteikšanās no turpmākas līdzdalības pētījumā tika respektēta, viņas kopējā datu analīzē netika iekḷautas.

2.1. tabula

Pacientu raksturojošie rādītāji un fizisko aktivitāšu līmenis pirms intervences

\begin{tabular}{|c|c|c|c|}
\hline & $\begin{array}{l}\text { MST grupa } \\
(n=27)\end{array}$ & $\begin{array}{l}\text { Kontroles } \\
\text { grupa }(n=28)\end{array}$ & P-vērtība \\
\hline Fizisko aktivitāšu iedalījums (\%) & & & 0,59 \\
\hline Zema intensitāte $-3.3 \mathrm{ME}$ & $22(82)$ & $21(75)$ & \\
\hline Mērena intensitāte $-4.0 \mathrm{ME}$ & $3(11)$ & $6(21)$ & \\
\hline Augsta intensitāte - 8.0 ME & $2(7)$ & $1(4)$ & \\
\hline Spēka treniņš & 0 & 0 & $<0,99$ \\
\hline Smēḳēšanas statuss (\%) & & & $<0,99$ \\
\hline Smēḳē & $3(11)$ & $3(10)$ & \\
\hline Smēḳēja & $1(4)$ & $2(7)$ & \\
\hline Nesmēkşē & $23(85)$ & $23(83)$ & \\
\hline Laulībā, attiecībās (\%) & $20(74)$ & $23(82)$ & 0,70 \\
\hline
\end{tabular}

Kategoriskie dati prezentêti kā skaidrs (n), (\%). MST; maksimālais spēka treniņš, ME, metaboliskais ekvivalents. Fiziskās aktivitātes līmenis tika novērtēts, izmantojot Starptautiskās fiziskās aktivitātes anketas saīsināto formu.

\subsection{Viena atkārtojuma maksimums}

Netika novērotas atšķirības starp grupām pacelto kilogramu skaitā pirmreizējā novērtēšanā viena atkārtojuma maksimumā (1AM) $(\mathrm{P}=0,187)$, (2.2. tabula), (2.1. attēls). 
Muskuḷu spēks krūts vēža pacientēm pirms un pēc intervences

\begin{tabular}{|c|c|c|c|c|}
\hline & $\begin{array}{c}\text { Pirms } \\
\text { Vidējā vērtība } \\
\quad \pm \text { SD }\end{array}$ & $\begin{array}{c}\text { Pēc } \\
\text { Vidējā vērtība } \\
\quad \pm \text { SD }\end{array}$ & $\begin{array}{c}\text { Vidējāa atškirīība } \\
(95 \% \text { CI })\end{array}$ & $\begin{array}{l}P \text {-vērtība un } \\
\text { Koena d- } \\
\text { vērtība pēc } \\
\text { intervences }\end{array}$ \\
\hline \multicolumn{5}{|l|}{$\begin{array}{l}\text { Viena atkārtojuma } \\
\text { maksimums (kg) }\end{array}$} \\
\hline MST & $106,8 \pm 22,8$ & $127,2 \pm 26,4$ & $20,4(17,3$ to 23,6$)$ & $\mathbf{0 , 0 0 1} ;(0,9)$ \\
\hline Kontroles & $98,9 \pm 20,7$ & $89,9 \pm 20,9$ & $-8,9(-11,0$ to $-6,9)$ & $\mathbf{0 , 0 0 1} ;(0,5)$ \\
\hline $\begin{array}{l}P \text {-vērtība un Koena } \\
\text { d-vērtība starp } \\
\text { grupām }\end{array}$ & 0,$19 ;(0,3)$ & $\mathbf{0 , 0 0 1} ;(1,6)$ & & \\
\hline
\end{tabular}

Dati tiek parādīti kā vidējā \pm standartnovirze. MST, maksimālā spēka treniṇa grupa. Kontroles - kontroles grupa.

- MST grupa apmeklēja $23 \pm 1$ no 24 plānotajām treniṇu sesijām $96 \pm 4$ \%.

- Pēc 12 nedēlu ilga intervences perioda MST grupai 1AM palielinājās par 20 $\pm 8 \%(\mathrm{P}<0,001)$.

- Turpretim kontroles grupā $1 \mathrm{AM}$ samazinājās par $9 \pm 5 \%(\mathrm{P}<0,001)$, salīdzinot rezultātus testos pirms un pēc intervences.

- $\quad 1 \mathrm{AM}$ ir augstāks MST grupā, salīdzinot ar kontroles grupu pēc 12 nedēlu intervences perioda ( $\mathrm{P}<0,001)$, (2.1. attēls). 


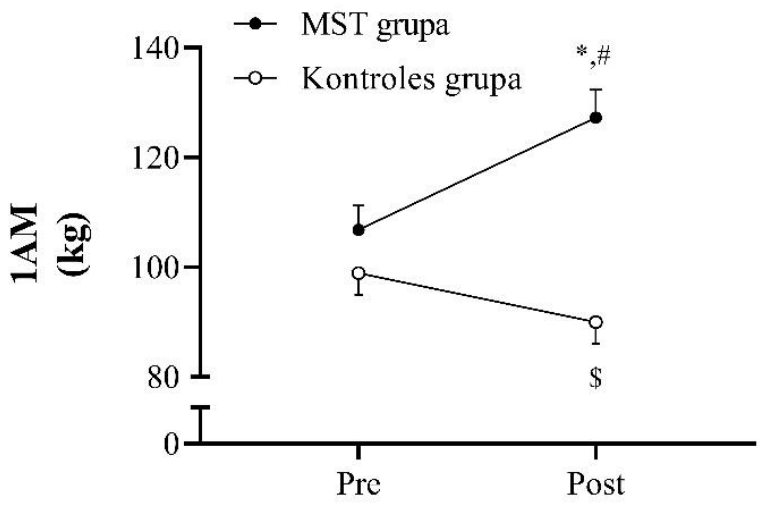

2.1. attēls. Viena atkārtojuma maksimums (1AM). Pre, pirms intervences. Post, pēc intervences. Dati ir prezentēti kā vidējā vērtība $\pm \mathrm{SE} .{ }^{*} \mathbf{p}<0,05$, vērtības pieaugums grupā no pirmreizējā testa līdz atkārtotam testam. $\$ p<0,05$, vērtības kritums grupā no pirmreizējā testa līdz atkārtotam testam. \# $\mathbf{p}<\mathbf{0 , 0 5}$, vērtības atšḳirība starp grupām no pirmreizējā testa līdz atkārtotam testam.

\subsection{Quadriceps femoris muskuḷa masa}

- Kontroles grupā Mqf samazinājās par $7 \pm 10 \%$, salīdzinot datus testos pirms un pēc intervences ( $\mathrm{P}<0,001)$, (2.2. attēls).

- MST grupā netika konstatētas izmaiņas, kā rezultātā Mqf MST grupā bija augstāks nekā kontroles grupā testā pēc atkārotas novērtēšanas $(\mathrm{P}<0,001)$.

- Izmaiņas Mqf bija saistītas ar izmaiṇām $1 \mathrm{AM}(\mathrm{r}=0,45 ; \mathrm{P}<0,001)$. 

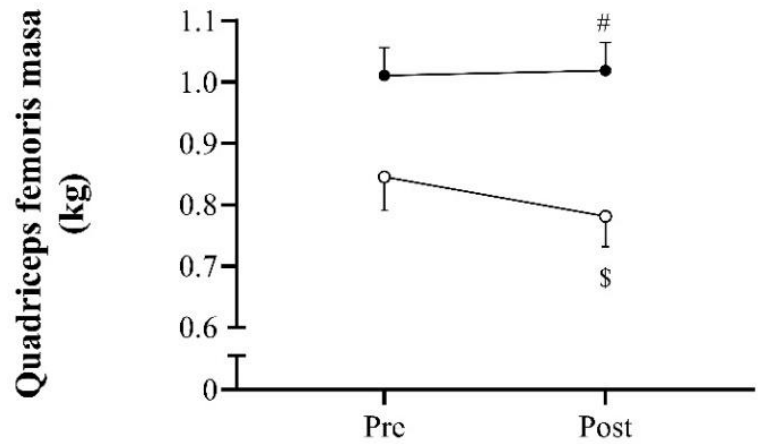

2.2. attēls. Quadriceps femoris muskuḷu masas izmaiņas pēc 12 nedēḷu intervences. Pre, pirms intervences. Post, pēc intervences. $\$ \mathbf{p}<0,05$, vērtības kritums grupas ietvaros. \# $\mathbf{p}<$ 0,05 , vērtības atškiirība starp grupām.

\subsection{Aerobo spēju rādītāji}

Fiziskā darba ekonomija un laiks līdz nogurumam ir prezentēti (2.3. tabulā).

- Uzlabojoties $1 \mathrm{AM}$, būtiski uzlabojās fiziskā darba ekonomija (9 $\pm 8 \%$ ) un palielinājās laiks līdz nogurumam iešanas laikā ar pakāpeniski augošu slodzes intensitāti $(9 \pm 8 \%$; abi $\mathrm{P}<0,01)$.

- Turpretī kontroles grupā pasliktinājās fiziskā darba ekonomija (4 \pm 4 \%) un samazinājās laiks līdz nogurumam $(10 \pm 8 \%$; abi $\mathrm{P}<0,01)$.

- Sajustās slodzes intensitātes pašnovērtējums (Borga skala), kā redzams (2.3. tabulā), salīdzinoši precīzi atbilst konkrētajai slodzei. Fiziskā darba ekonomijas testa laikā intensitāte, kas atbilst 40 vatiem, tagad prasa ievērojami lielāku piepūli kontroles grupai, salīdzinot ar MST grupu. Testā līdz nogurumam visas pacientes spēja sasniegt augstu intensitāti noguruma testa beigās, gan veicot pirmreizēju, gan atkārtotu novērtēšanu. 
Aerobo spēju rādītāji pirms un pēc intervences

\begin{tabular}{|c|c|c|c|c|}
\hline & Pirms & Pēc & $\begin{array}{c}\text { P-vēetība } \\
\text { pēc } \\
\text { intervences }\end{array}$ & $\begin{array}{c}\text { Mijiedarbība } \\
\text { (Laiks x } \\
\text { Grupa) }\end{array}$ \\
\hline \multicolumn{5}{|l|}{ Fiziskā darba ekonomija } \\
\hline \multicolumn{5}{|l|}{$\mathrm{SF}\left(\right.$ sitieni $\left.\cdot \mathrm{min}^{-1}\right)$} \\
\hline MST & $140 \pm 16$ & $128 \pm 15$ & $<0,001$ & $<0,001$ \\
\hline Kontroles & $134 \pm 12$ & $149 \pm 12$ & $\mathbf{0 , 0 0 2}$ & \\
\hline$P-v \bar{e} r t \bar{b}$ a starp grupām & 0,150 & 0,009 & & \\
\hline \multicolumn{5}{|l|}{ Borga skala $(6-20)$} \\
\hline MST & $12 \pm 1$ & $10 \pm 2$ & $<0,001$ & $<0,001$ \\
\hline Kontroles & $12 \pm 2$ & $13 \pm 1$ & 0,184 & \\
\hline$P-$ vērtība starp grupām & 0,289 & $<0,001$ & & \\
\hline \multicolumn{5}{|l|}{ Inkrementāls slodzes tests } \\
\hline \multicolumn{5}{|l|}{$\mathrm{TE}(\mathrm{s})$} \\
\hline MST & $536 \pm 71$ & $571 \pm 68$ & $<0,001$ & $<0,001$ \\
\hline Kontroles & $531 \pm 73$ & $476 \pm 63$ & $<0,001$ & \\
\hline$P$ - vērtība starp grupām & 0,814 & $<0,001$ & & \\
\hline \multicolumn{5}{|l|}{$\mathrm{SF}_{\max }\left(\operatorname{sitieni} \cdot \min ^{-1}\right)$} \\
\hline MST & $172 \pm 8$ & $172 \pm 7$ & $<0,99$ & 0,443 \\
\hline Kontroles & $167 \pm 11$ & $166 \pm 11$ & 0,275 & \\
\hline$P-$ vērtība starp grupām & 0,042 & 0,013 & & \\
\hline \multicolumn{5}{|l|}{$\bar{A}$ trums $\left(\mathrm{km} \cdot \mathrm{h}^{-1}\right)$} \\
\hline MST & $4,8 \pm 0,4$ & $5,1 \pm 0,4$ & $<0,001$ & $<0,001$ \\
\hline Kontroles & $4,8 \pm 0,5$ & $4,7 \pm 0,3$ & $\mathbf{0 , 0 0 2}$ & \\
\hline$P$ - vērtība starp grupām & 0,454 & 0,001 & & \\
\hline \multicolumn{5}{|l|}{ Slīpums (\%) } \\
\hline MST & $11 \pm 1$ & $12 \pm 1$ & 0,009 & $<0,001$ \\
\hline Kontroles & $11 \pm 1$ & $10 \pm 2$ & 0,003 & \\
\hline$P-v \bar{e} r t \bar{b} b a$ starp grupām & 0,402 & 0,010 & & \\
\hline \multicolumn{5}{|l|}{ Borga skala (6-20) } \\
\hline MST & $17 \pm 1$ & $18 \pm 1$ & 0,120 & 0,475 \\
\hline Kontroles & $17 \pm 1$ & $17 \pm 1$ & 0,563 & \\
\hline$P$ - vērtība starp grupām & 0,975 & 0,372 & & \\
\hline
\end{tabular}

Dati ir prezentēti kā vidējā \pm standartnovirze. MST; maksimālā spēks treniņš, HR; sirdsdarbības frekvence, Borga skala, slodzes intensitātes pašnovērtējums. TE; laiks līdz testa pārtraukšanai. $\mathrm{SF}_{\max }$; maksimālā sirdsdarbības frekvence. 


\subsection{Funkcionālās spējas}

- Pēc atkārtotas novērtēšanas MST grupa demonstrēja uzlabojumus visos funkcionālo spēju testos, 6MWD uzlabojās par (10 \pm 7 \%), (2.3. attēls), piecelšanās un apsēšanās reizes no krēsla par (30 20 \%), (2.4. attēls), un pakāpienu testa laiks samazinājās par $(12 \pm 7 \%$; visi $\mathrm{P}<0,001)$, parādīts (2.5. attēlā).

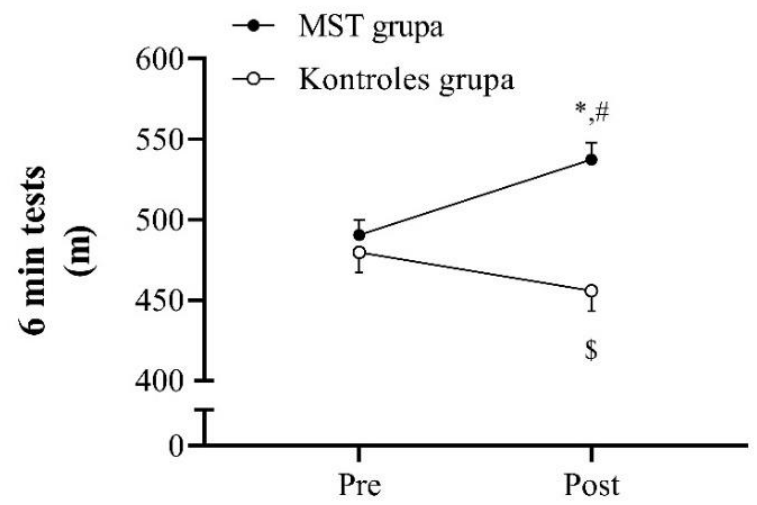

2.3. attēls. 6 minūšu iešanas tests. Dati ir prezentēti kā vidējā vērtība \pm SE. Pre, pirms intervences. Post, pēc intervences. * $p$ $<0,05$, vērtības pieaugums grupā no pirmreizējā testa līdz atkārtotam testam. $\$ p<0,05$, vērtības kritums grupā no pirmreizējā testa līdz atkārtotam testam. \# p < 0,05, atškirīība starp grupām no pirmreizējā testa līdz atkārtotam testam. 


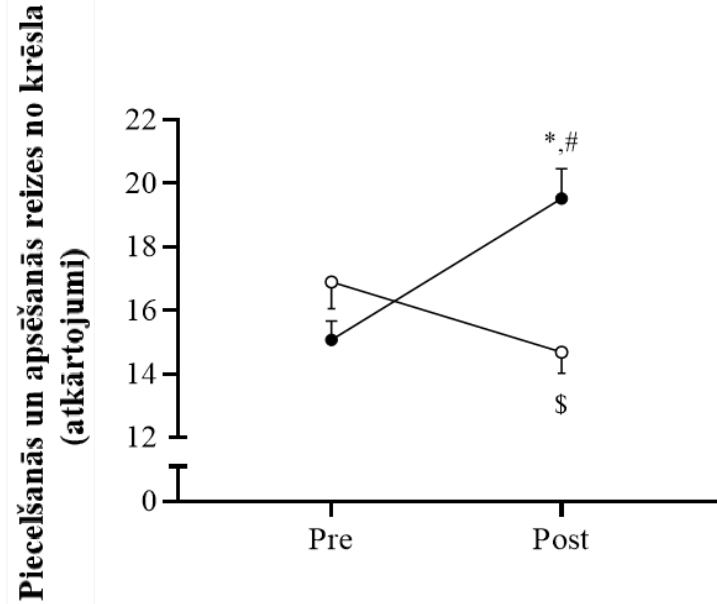

2.4. attēls. Piecelšanās un apsēšanās tests. Dati ir prezentēti kā vidējā vērtība \pm SE. Pre, pirms intervences. Post, pēc intervences. * $\mathbf{p}<0,05$, vērtības pieaugums grupā no pirmreizējā testa līdz atkārtotam testam. $\$ p<0,05$, vērtības samazinājums grupā no pirmreizējā testa līdz atkārtotam testam. \# $p<0,05$, atšķirība starp grupām no pirmreizējā testa līdz atkārtotam testam.

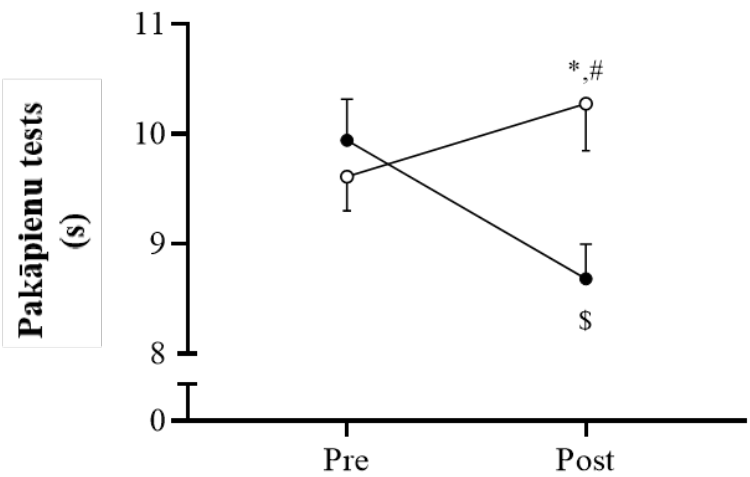

2.5. attēls. Pakāpienu tests. Dati ir prezentēti kā vidējā vērtība \pm SE. Pre, pirms intervences. Post, pēc intervences. * $\mathbf{p}<0,05$, vērtības pieaugums grupā no pirmreizējā testa līdz atkārtotam 
testam. \$ p $<0,05$, vērtības samazinājums grupā no pirmreizējā testa līdz atkārtotam testam. \# p < 0,05, atšķirība starp grupām no pirmreizējā testa līdz atkārtotam testam.

- Savukārt kontroles grupā rezultātu pasliktināšanās tika konstatēta: 6MWD $(5 \pm 5 \%)$, piecelšanās un apsēšanās testā $(12 \pm 12 \%)$ un pakāpienu testā $(6 \pm 8 \%$; visi $\mathrm{P}<0,001)$.

- Testos pēc intervences 6MWD $(\mathrm{P}<0,001)$, piecelšanās un apsēšanās no krēsla $(\mathrm{P}<0,001)$ un pakāpienu testā $(\mathrm{P}=0,004)$ tika novērotas statistiski lielas atškirīības starp grupām.

- Izmaiņas 1AM korelē ar izmaiņām fiziskā darba ekonomijā $(\mathrm{r}=0,754)$, laikā līdz nogurumam $(\mathrm{r}=0,793), 6$ minūšu iešanas testa noietajā distancē $(\mathrm{r}=0,807)$, piecelšanās un apsēšanās testa reizēs $(\mathrm{r}=0,808)$ un pakāpienu testa rezultātos $(\mathrm{r}=0,754 ; \mathrm{p}<0,001),(2.6$. attēls $)$.

- $\quad$ MST grupa

A

- Kontroles grupa

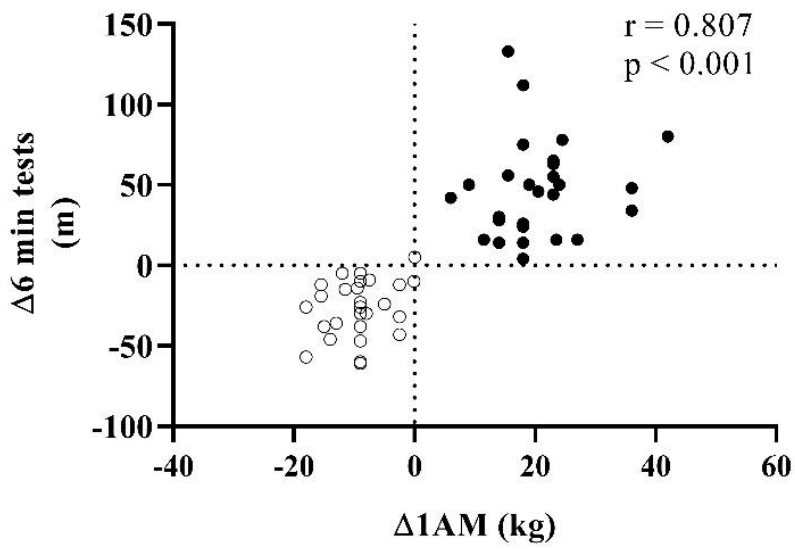


B

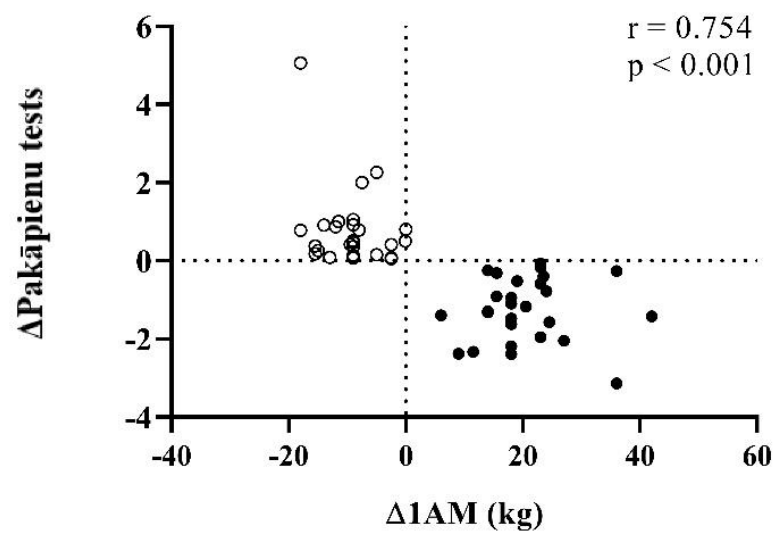

C

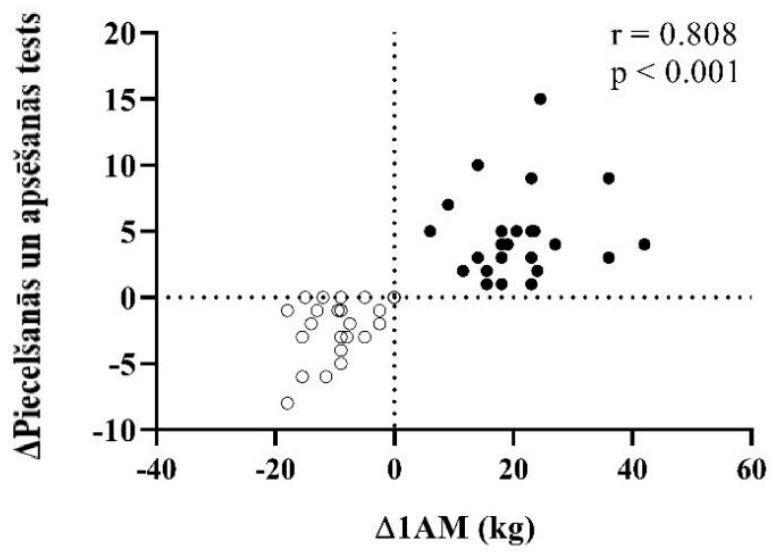




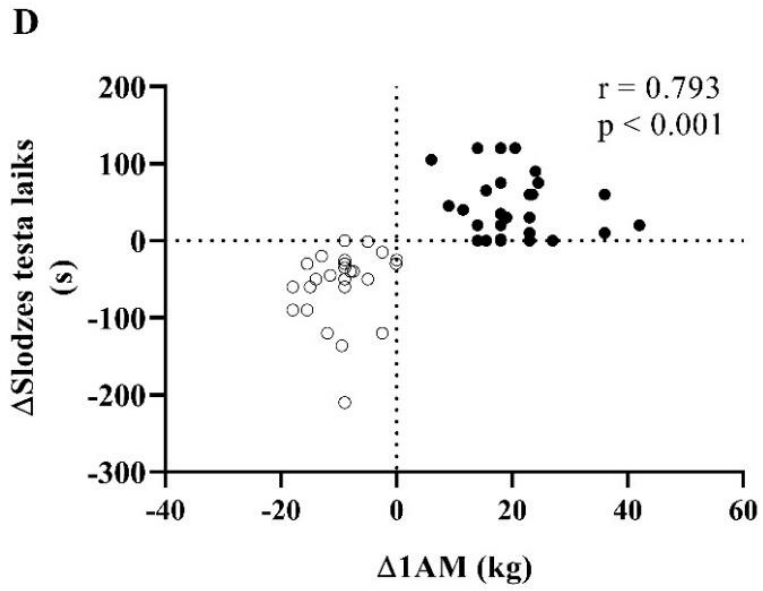

$\mathbf{E}$

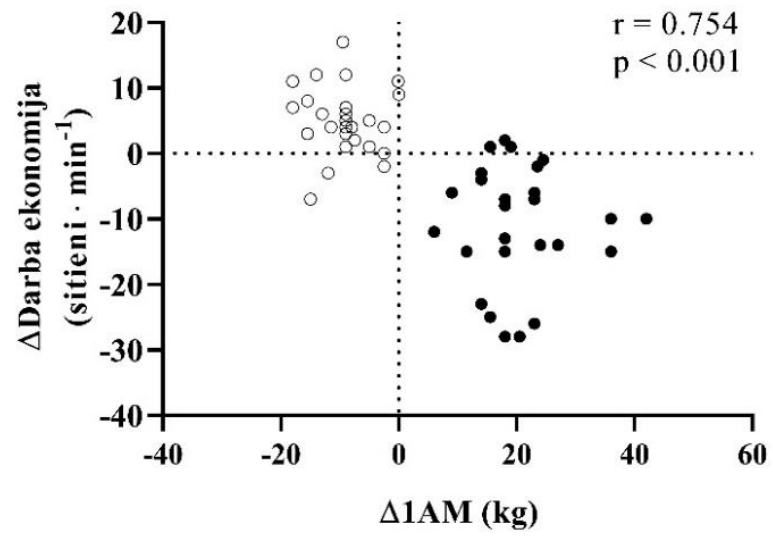

2.6. attēls. Korelācija starp izmaiņām maksimālajā spēkā (viena atkārtojuma maksimums) un izmaiṇām (A) 6 minūšu iešanas testa noietajā distancē, (B) pakāpienu testa rezultātos, (C) piecelšanās un apsēšanās no krēsla rezultātā, (D) laikā līdz nogurumam iešanas laikā ar pakāpeniski pieaugošu intensitāti un (E) fiziskā darba ekonomijā pēc 12 nedẹlu krūts vēža adjuvantas terapijas ar maksimālā spēka treniņu (MST) un bez tā. 


\subsection{Dzīves kvalitāte, kas saistīta ar veselību}

Pēc 12 nedēḷ intervences perioda MST grupai un kontroles grupai tika novērtētas izmaiņas dzīves kvalitātē, kas saistīta ar veselību, izmantojot Eiropas Vēža izpētes un ārstēšanas organizācijas "Dzīves kvalitātes novērtēšanas anketu" C30 (2.4. tabula) un papildu krūts vēža moduli BR23 (2.5. tabula).

\section{Pamata anketa; QLQ-C30}

Būtiskas sākotnējo vērtību atškirīības starp grupām netika novērotas $(\mathrm{p}>0,05)$, (2.4. tabula).

\section{Vispārējais veselības stāvoklis/QoL}

- Vispārējais veselības stāvoklis/QoL (QoL) MST grupai ievērojami uzlabojās - par $13 \%(P=0,002, d=0,6)$ ar lielu efektu, bet kontroles grupā netika novērotas izmaiņas $(\mathrm{P}=0,44, \mathrm{~d}=0,2)$. Rezultāti, kas iegūti pēcintervences periodā, uzrāda ievērojamas atškirirības QoL starp grupām ar l̦oti lielu efekta iedarbību $(\mathrm{P}=0,002, \mathrm{~d}=0,9)$.

- 1AM uzlabojumi korelē ar QoL izmaiņām ( $\mathrm{r}=0,60 ; \mathrm{P}<0,001),(2.7$. attēls). 


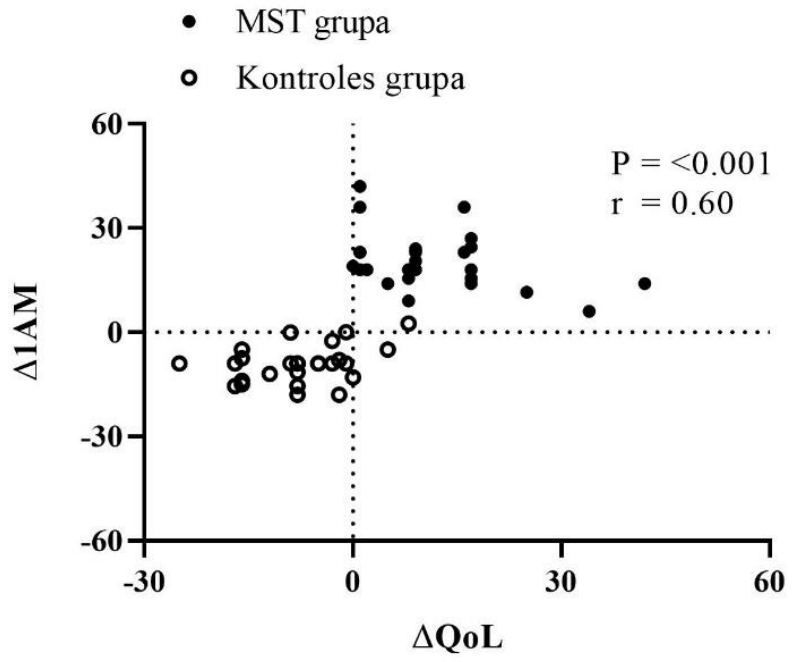

2.7. attēls. Korelācija starp maksimālā spēka izmaiṇām (viena atkārtojuma maksimums 1AM, izmantojot trenažieri spiešanai ar kājām) un vispārējā veselības stāvokḷa/QoL (QoL) izmaiṇām pēc 12 nedēlu ilgas krūts vēža adjuvantas terapijas ar maksimālo spēka treninu (MST) vai bez tā.

\section{Funkciju skalas}

- Lomu pildī̌sana MST grupā uzlabojās par $23 \%(\mathrm{P}=0,001, \mathrm{~d}=0,7)$, sociālā funkcionēšana par $12 \%(P=0,01, d=0,5)$, emocionālā funkcionēšana par $13 \%(\mathrm{P}=0,001, \mathrm{~d}=0,5)$, kamēr tā pasliktinājās kontroles grupā par $11 \%$ $(\mathrm{P}=0,02, \mathrm{~d}=0,4)$

- Pēc atkārtotas novērtēšanas tika novērotas būtiskas atškirīības starp abām grupām emocionālajā funkcionēšanā $(\mathrm{P}=0,005, \mathrm{~d}=0,7)$ un sociālajā funkcionēšanā ar ḷoti lielu efekta ietekmi $(P=0,004, d=0,9)$.

- Pārējās funkcionālās skalās - fiziskā funkcionēšana un kognitīvā funkcionēšana - netika novērotas izmaiņas grupās, salīdzinot testus pirms un pēc intervences. Tomēr fiziskā funkcionēšana būtiski uzlabojās ar ḷoti 
lielu efektu MST grupā, salīdzinot ar testa rezultātiem pēc intervences kontroles grupai $(P=0,003, d=0,9)$.

\section{Simptomu skalas}

- $\quad$ Ar vēzi saistîts nogurums (CRF) MST grupā samazinājās par 24 \% (P = $0,03, d=0,6)$, bet kontroles grupā tas kḷuva izteiktāks par $25 \%(P=0,02$, $\mathrm{d}=0,4)(2.4$. tabula). Tika novērotas atšķirīibas starp grupām ar lielu efektu pēc atkārtotas novērtēšanas $(\mathrm{P}=0,01, \mathrm{~d}=0,6)$.

2.4. tabula

Eiropas Vēža izpētes un ārstēšanas organizācijas anketa (QLQ-C30)

\begin{tabular}{|c|c|c|c|}
\hline Mainīgie & $\begin{array}{c}\text { Pirms } \\
\text { Vidējā vērtība } \\
\pm \mathrm{SD} \\
\end{array}$ & $\begin{array}{c}\text { Pēc } \\
\text { Vidējā vērtība } \\
\pm \mathrm{SD} \\
\end{array}$ & $\begin{array}{l}\text { P-vērtība un } \\
\text { Koena d vērtība } \\
\text { pēc intervences }\end{array}$ \\
\hline \multicolumn{4}{|l|}{$\begin{array}{l}\text { Vispārējais veselības } \\
\text { stāvoklis / QoL }\end{array}$} \\
\hline MST & $67,2 \pm 15,6$ & $76,2 \pm 14,3$ & $\mathbf{0 , 0 0 2} ;(0,6)$ \\
\hline Kontroles & $66,3 \pm 16,5$ & $63,5 \pm 14,7$ & 0,$44 ;(0,2)$ \\
\hline $\begin{array}{l}\text { P vērtība un Koena d } \\
\text { verrtība starp grupām }\end{array}$ & 0,$84 ;(0,1)$ & $\mathbf{0 , 0 0 2} ;(0,9)$ & \\
\hline \multicolumn{4}{|l|}{ Funkciju skalas } \\
\hline \multicolumn{4}{|l|}{ Fiziskā funkcionēšana } \\
\hline MST & $88,6 \pm 8,2$ & $90,6 \pm 6,4$ & 0,$17 ;(0,3)$ \\
\hline Kontroles & $84,2 \pm 14,6$ & $81,6 \pm 13,2$ & $\mathbf{0 , 0 7} ;(0,2)$ \\
\hline $\begin{array}{l}\text { P vērtība un Koena d } \\
\text { vērtība starp grupām }\end{array}$ & 0,$18 ;(0,3)$ & $\mathbf{0 , 0 0 3} ;(0,9)$ & \\
\hline \multicolumn{4}{|l|}{ Lomu izpilde } \\
\hline MST & $70,0 \pm 26,7$ & $85,9 \pm 18,2$ & $\mathbf{0 , 0 0 1} ;(0,7)$ \\
\hline Kontroles & $69,1 \pm 25,5$ & $77,0 \pm 19,5$ & 0,$13 ;(0,4)$ \\
\hline $\begin{array}{l}\text { P vērtība un Koena d } \\
\text { vērtība starp grupām }\end{array}$ & 0,$89 ;(0,01)$ & $\mathbf{0 , 0 9} ;(0,01)$ & \\
\hline \multicolumn{4}{|l|}{ Emocionālā funkcionēšana } \\
\hline MST & $72,4 \pm 21,1$ & $82,1 \pm 18,8$ & $\mathbf{0 , 0 0 2} ;(0,5)$ \\
\hline Kontroles & $74,4 \pm 23,9$ & $66,3 \pm 21,3$ & 0,$02 ;(0,4)$ \\
\hline $\begin{array}{l}\text { P vērtība un Koena d } \\
\text { verrtība starp grupām }\end{array}$ & 0,$76 ;(0,1)$ & $\mathbf{0 , 0 0 5} ;(0,8)$ & \\
\hline
\end{tabular}


2.4. tabulas turpinājums

\begin{tabular}{|c|c|c|c|}
\hline Mainīgie & $\begin{array}{c}\text { Pirms } \\
\text { Vidējā vērtība } \\
\quad \pm \text { SD }\end{array}$ & $\begin{array}{c}\text { Pēc } \\
\text { Vidējā vērtība } \\
\pm \mathrm{SD}\end{array}$ & $\begin{array}{l}P \text {-vērtība un } \\
\text { Koena d vērtība } \\
\text { péc intervences }\end{array}$ \\
\hline \multicolumn{4}{|l|}{ Kognitīvā funkcionēšana } \\
\hline MST & $86,3 \pm 15,4$ & $87,0 \pm 14,1$ & 0,$83 ;(0,1)$ \\
\hline Kontroles & $86,2 \pm 18,2$ & $80,8 \pm 19,5$ & 0,$11 ;(0,3)$ \\
\hline $\begin{array}{l}P \text { vērtība un Koena d } \\
\text { vērtība starp grupām }\end{array}$ & 0,$99 ;(0,1)$ & 0,$19 ;(0,4)$ & \\
\hline \multicolumn{4}{|l|}{ Sociālā funkcionēšana } \\
\hline MST & $76,4 \pm 24,1$ & $85,7 \pm 16,4$ & $\mathbf{0 , 0 1} ;(0,5)$ \\
\hline Kontroles & $74,3 \pm 27,3$ & $70,2 \pm 20,9$ & 0,$29 ;(0,2)$ \\
\hline $\begin{array}{l}P \text { vērtība un Koena d } \\
\text { vērtība starp grupām }\end{array}$ & 0,$76 ;(0,1)$ & $\mathbf{0 , 0 0 4} ;(0,8)$ & \\
\hline \multicolumn{4}{|l|}{ Simptomu skalas } \\
\hline \multicolumn{4}{|l|}{ Nogurums } \\
\hline MST & $33,5 \pm 17,1$ & $25,5 \pm 15,5$ & $\mathbf{0 , 0 3} ;(0,6)$ \\
\hline Kontroles & $29,5 \pm 18,5$ & $36,8 \pm 16,7$ & 0,$16 ;(0,4)$ \\
\hline $\begin{array}{l}\text { P vērtība un Koena d } \\
\text { vērtība starp grupām }\end{array}$ & 0,$41 ;(0,2)$ & $\mathbf{0 , 0 1} ;(0,6)$ & \\
\hline
\end{tabular}

Dati ir prezentēti kā vidējās vērtības \pm standartnovirze. MST, maksimālā spēka treniņa grupa. Kontroles - kontroles grupa.

\section{Krūts vēža modulis QLQ-BR23}

Izmaiņas EORTC QLQBR23 papildu modulī ir prezentētas (2.5. tabulā).

\section{Funkciju skalas}

- Kontroles grupā testā pēc intervences tika novērotas izmaiṇas sava ķermeṇa uztverē (priekšstats par ķermeņa tēlu) $(P=0,05, d=4)$. Šis rādītājs nemainījās MST grupā, bet uzrādīja vidējas nozīmes efekta ietekmi $(P=0,2, d=0,3)$.

\section{Simptomu skalas}

- Kontroles grupā sistēmiskās terapijas blaknes būtiski pastiprinājās ar lielu efekta ietekmi ( $(\mathrm{P}=0,001, \mathrm{~d}=0,8)$, bet MST grupā nebija nozīmīgu izmaiṇu 
$(\mathrm{P}=0,4, \mathrm{~d}=0,3)$. Savukārt nozīmīgas atšķirības ar lielu ietekmi $(\mathrm{P}=0,04$, $\mathrm{d}=0,5)$ tika novērotas starp grupām pēc intervences.

2.5. tabula

Izmaiṇas Eiropas Vēža izpētes un ārstēšanas organizācijas papildu modelī QLQ-BR23

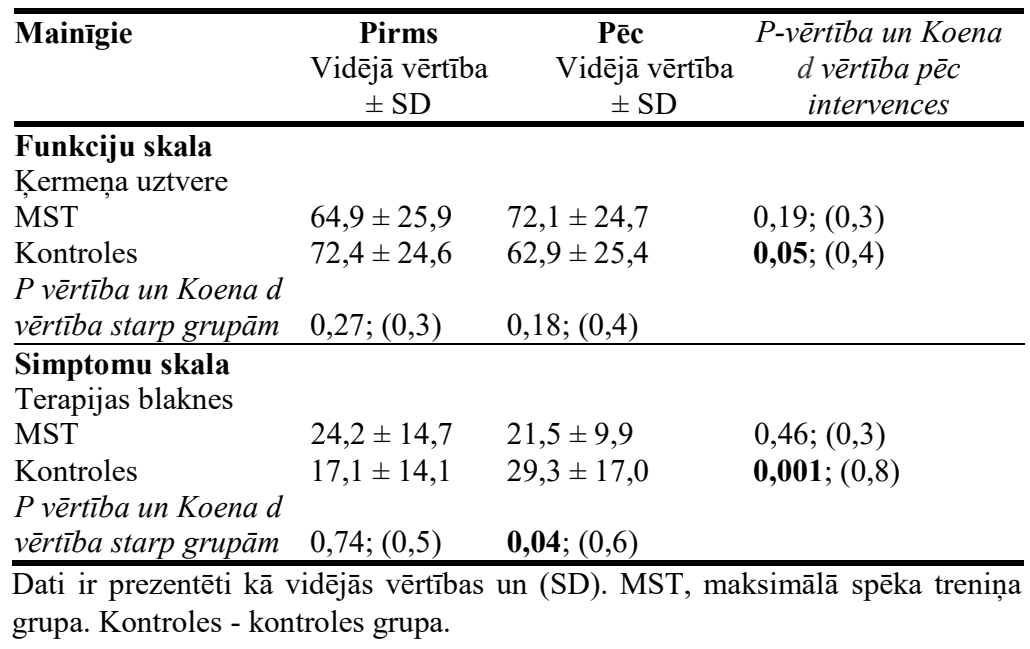




\section{Diskusija}

Adjuvanta KV terapija ir saistīta ar muskuḷu spēka, muskuḷu masas un fiziskās aktivitātes samazināšanos (Irwin et al., 2003), (Klassen et al., 2017), (Mijwel et al., 2018c), kas pasliktina kopējo ar veselību saistīto dzīves kvalitāti (DzK) (Mijwel et al., 2018a). Neraugoties uz labi dokumentētu spēka treniņu efektivitāti, lai uzlabotu šos faktorus citās pacientu grupās, ir maz pierādījumu par spēka treniņu, jo īpaši piemērojot augstāku intensitāti KV ārstēšanas sākumposmā.

Tādēḷ šajā pētījumā autors izvirzīja mērḳi izpētît spēka treniņu ietekmi uz funkcionāli nozīmīgajām apakšējām ekstremitātēm, izmantojot augstāku intensitāti ( 90 \% 1AM), veicot četras sērijas (4) un četrus atkārtojumus katrā sērijā pirmreizēji diagnosticētām KV pacientēm, kas saņem adjuvantu ķīmijterapiju. Galvenie secinājumi: trīs mēnešus ilgs MST ievērojami paaugstināja apakšējo ekstremitāšu maksimālo muskuḷu spēku, kas sekmēja fiziskā darba ekonomijas un funkcionālo spēju paaugstināšanos, kā arī saglabāja muskuḷu masu. Turklāt muskuḷu spēka pieaugums veicināja DzK, jo īpaši uzlabojot lomu funkciju, emocionālo noturību, sociālo funkcionēšanu, vienlaikus samazinot ar vēzi saistīto nogurumu (CRF). Svarīgi, ka regulārs spēka treniņš ir uzlabojis priekšstatu par ķermeṇa uztveri un mazinājis ārstēšanas laikā radušās blaknes. Savukārt pacientēm, kuras tika iekḷautas kontroles grupā un kuras saņēma tikai nozīmēto terapiju bez spēka treniņiem, tika konstatēts visu mērīto parametru samazinājums. Lielākā dą̧a pacienšu nebija fiziski aktīvas, uzsākot adjuvantu ārstēšanu, tāpēc ir pierādīts un mūsu novērojumi to apstiprina, ka zemāks fiziskās aktivitātes līmenis var palielināt risku tikt diagnosticētam ar vēzi (McTiernan et al., 2019). Šā pētījuma rezultāti papildina jau iepriekš konstatēto, kas pamato strukturētu spēka treniņu programmu iekḷaušanu KV pacientu ārstēšanas procesā. Vēlams to uzsākt laikus pēc operācijas, pirms adjuvantas ķīmijterapijas, lai saglabātu vai pat uzlabotu fizisko un garīgo veselību. 


\subsection{Muskuḷu spēka izmainas}

Viens no primārajiem spēka treniṇa mērḳiem ir veicināt neiromuskulāro funkciju adaptāciju. Izmantotās spēka treniņu programmas KV pacientēm ievērojami atšķiras attiecībā uz treniņu apjomu (paveiktā darba apjoms: tostarp atkārtojumu skaits un kopējais sēriju skaits vienā treniņā), biežumu (cik bieži konkrēts vingrojums tiek izpildīts vai cik bieži konkrēts muskulis tiek trenēts) un intensitāti (svars procentuāli no 1AM, kas ir izmantots slodzes laikā) (al-Majid and McCarthy, 2001), (Campbell et al., 2012).

Lielākā daḷa spēka treniņu pētījumu onkolog̣ijā izmanto zemu vai vidēju treniņu intensitāti $<75 \%$ 1AM, izmantojot 1-3 sērijas un veicot $\geq 8$ atkārtojumus. Parasti treniņu intervence ilgst no 4 nedēḷām līdz pat 12 mēnešiem, treniṇu programmas tiek īstenotas klīniskajā vidē vai mājās, sazinoties ar speciālistu attālināti; vingrinājumi tiek veikti ar lēnu kustību koncentriskajā fāzē, un treniṇu uzsākšana parasti sākas pēc primārās ārstēšanas pabeigšanas (Wernbom et al., 2007), (Schmitz et al., 2010), (Hagstrom et al., 2019). Tāpēc arvien lielāku atzinību gūst nepieciešamība paplašināt zināšanas un īstenot praktiskas spēka treniņa metodikas onkolog̣ijā. Līdz ar to ir nepieciešamas labi izstrādātas un precīzi definētas spēka treniņu metodes ar lielāku spēka treniṇu intensitāti. Analizējot pieejamo informāciju, šis pētījums ir pirmais, kas klīniskajā vidē izvērtē austākās intensitātes spēka treniņu ietekmi KV pacientēm adjuvantas ķ̄imijterapijas laikā.

Šajā pētījumā kontroles grupai, saņemot standarta adjuvantas terapiju bez spēka treniņiem, par $9 \%$ samazinājās maksimālais muskuḷu spēks apakšējās ekstremitātēs, kas konstatējams jau pēc 12 nedēlu ilgas adjuvantas terapijas un kas atbilst vairāk nekā desmit gadu ilgam tipiskam novecošanas procesam (Lindle et al., 1997), savukārt MST grupas pacientes divas reizes nedēḷā veica MST un pēc trim mēnešiem tām bija par 30 \% lielāks maksimālais muskuḷu spēks nekā kontroles grupai. Straujais muskuļu spēka kritums kontroles grupai 
labi parāda esošo situāciju, ar ko saskaras lielākā daḷa onkoloǵijas pacientu, saņemot pretvēža ārstēšanos bez mērķtiecīgām fizisko aktivitāšu programmām. Būtiski uzsvērt, ka MST inducētā iedarbība ir līdz̄̄ga tai, kas tipiski tiek novērota veselu indivīdu un citu pacientu populācijā, kad tiek izmantota augstāka intensitāte spēka treniṇu laikā, izmantojot trenažieri spiešanai ar kājām (Hoff et al., 2002), (Hoff et al., 2007), (Wang et al., 2010), (Helgerud et al., 2011). MST iedarbība ir pētīta hronisku obstruktīvu plaušu slimību (HOPS) un perifēro artēriju slimības pacientiem (PAS). Pat ja patoloǵijas ir atškirīigas no onkoloǵijas pacientiem, gan HOPS, gan PAS un KV pacientēm ir pazeminātas fiziskās spējas. Tomēr muskuḷu spēka pieaugums pēc spēka treniņu intervencēm ir līdzīgi augsts gan HOPS, gan PAD pacientiem un KV pacientēm. Ir pārsteidzoši, ka MST izraisa līdzīgus spēka uzlabojumus personām visos vecumos ar atškirīgu fizisko spēju līmeni un dažādās pacientu populācijās, ja intensitāte tiek uzturēta nemain̄̄gi augsta. Nozīmīgi, ka 20 kg uzlabojums 1AM, izmantojot trenažieri spiešanai ar kājām MST grupā, ir aptuveni 2,5 reizes lielāks nekā citā pētījumā novērotais $\sim 8 \mathrm{~kg} 1 \mathrm{AM}$ pieaugums, kur pacientes trenējās trīs reizes nedēḷā ar intensitāti, kas atbilst 60-70 \% 1AM (Courneya et al., 2007b).

Ir vairāki mehānismi, ar ko varētu izskaidrot salīdzinoši lielu spēka pieaugumu, neraugoties uz saņemto adjuvantas ķīmijterapiju. Atkārtotas, regulāras, epizodiskas muskuḷu kontrakcijas, kas saistītas ar spēka treniņu, veicina virkni fizioloǵisko adaptāciju un laika periodā potenciāli maina skeleta muskuḷu fenotipu; tostarp izmaiņas kontraktilajā struktūrā, mitohondriju funkcijā, vielmaiņas regulēšanā un starpšūnu komunikācijā, kontraktilā proteīna daudzumā un saistaudu elastīgumā (Wernbom et al., 2007). Adaptācijas spēka treniņu rezultātā parasti novēro pēc 8 līdz 12 nedēḷām (Folland and Williams, 2007), palielinot muskuļu masas pieaugumu - hipertrofija, palielinot šķērsgriezuma laukumu, uzlabotu nervu impulsa pārvades ātrumu un uzlabotu muskuḷu spēku. Adaptācijas, kas novērojamas neiromuskulārajā sistēmā, pamatā 
ir motorā mācīšanās (kustības izpratne, pielāgošanās, dzīvā ķermeņa pieredze), motoro vienību sinhronizācija, muskuḷu iesaiste un palielināta nervu impulsa aktivizācija (Endo et al., 2020). Šiem nervu sistēmas adaptācijas faktoriem ir svarīga nozīme muskuḷu spēka pieaugumā, kas tiek vairāk nodarbināti, veicot efektīvus spēka treniņus ar lielāku intensitāti.

Tipiski MST uzlabo gan maksimālo muskuḷu spēku, gan spēka attīstības ātrumu (RFD), un parasti RFD uzlabojumi sasniedz no $26 \%$ līdz 60 \%. RFD ir būtiska loma personas funkcionalitātē, saglabājot neatkarības līmeni ikdienas aktivitātēs (Heggelund et al., 2013), (Unhjem et al., 2016). Lai gan RFD šajā pētījumā netika mērīts, iespējams, ka līdzīgi uzlabojumi varētu būt novēroti KV pacientēm, kuras piedalījās MST. Šo novērojumu apstiprina arī uzlabota fiziskā darba ekonomija, ko galvenokārt saista ar uzlabotu RFD (Støren et al., 2008). Turpretim kontroles grupa, kura trīs reizes nedēḷa veica piecelšanos un apsēšanos no krēsla, nesasniedza nepieciešamo minimālo intensitāti, tādējādi nenodrošinot pietiekamu stimulu motoro vienību aktivizēšanai, un dalībnieču muskuḷu spēks samazinājās, kā arī samazinājās fiziskā darba ekonomija un funkcionālās spējas.

Samazināts muskuḷu spēks un RFD ir saistīts ar lielāku kritienu un kaulu lūzumu risku (Moreland et al., 2004). Lielāks personas vecums, pretvēža ārstēšanas blaknes un samazināts kaulu blīvums (Winters-Stone et al., 2013) kopā ar samazinātu RFD rada KV pacientēm lielāku kritienu risku un ierobežo līdzdalību ikdienas aktivitātēs.

\subsection{Muskuḷu masas izmaiṇas}

Muskuḷu atrofija vai ar vēzi saistīta muskuḷu masas samazināšanās jeb kaheksija var rasties dažādu fizioloǵisko un patologiisko procesu rezultātā. Kaheksija ir nāves cēlonis aptuveni 2 miljoniem cilvēku visā pasaulē, un tā ievērojami samazina DzK (Burckart et al., 2010), kas ir bieža blakne onkoloğijā, un bieži pastiprinās pretvēža ārstēšanas rezultātā un var liecināt par sliktāku 
prognozi, kā arī pasliktina onkoloǵisko pacientu līdzdalību ikdienas aktivitātēs (Mazzuca et al., 2018). Kaheksija ir saistīta ar aptuveni $80 \%$ smagu vēža gadījumu, un tā ir par iemeslu vairāk nekā 30 \% visu vēža izraisītu nāves gadījumu (Isaac, Tan et al., 2015).

Ar vēzi saistītie muskuḷu masas krituma molekulārie mehānismi nav pilnībā noskaidroti. Pieejamie pierādījumi liecina, ka ievērojama nozīme ir palielinātai muskuḷu olbaltumvielu degradācijai un traucētai muskuḷu olbaltumvielu sintēzei, kā arī nepietiekamai mioǵenēzei. Vairāki faktori, iespējams, veicina izmaiņas, kas rada muskuḷu masas samazinājumu, piemēram, vairāki iekaisumu veicinoši citokīni, kurus rada noteiktas audzēja šūnas: audzēja nekrozes faktors alfa (TNF- $\alpha$ ), interleikīns 1 (IL-1 $\alpha, \beta)$, interleikīns-6 (IL-6), gamma interferons - (IFN- $\gamma$ ), leikēmiju inhibējošais faktors (LIF), ciliārais neirotrofiskais faktors (SNTF) (Schneider, Hsieh et al., 2007), (Battaglini et al., 2012). Šie iekaisuma mediatori un audzēju šūnas ierobežo anabolismu un palielina katabolismu, kas veicina muskuḷu masas zudumu, kas rodas olbaltumvielu sintēzes samazināšanās un palielinātas olbaltumvielu degradācijas dēḷ (Argiles, Costelli et al., 1999), (Yakovenko et al., 2018). Ja šī fiziologiskāā atbildes reakcija/pielāgošanās netiek konstatēta, tā pakāpeniski samazina funkcionālās spējas un tādējādi pasliktina DzK. Arī izmaiņas enerğijas metabolismā, tostarp mitohondriju disfunkcija, ir saistītas ar muskuļu masas samazināšanās procesu onkoloğijas gadījumā (Johns et al., 2013). Piemēram, lai gan kontraktilo olbaltumvielu zudums galvenokārt ietekmē muskuḷu II tipa "ātrās" šķiedras, novecošanas vai vēža kaheksijas rezultātā proporcionāli palielinās I tipa "lēno” šķiedru skaits pret "ātrajām” šķiedrām (Fanzani et al., 2012). Šīs izmaiņas kombinācijā ar pretvēža terapiju un spēka treniņu trūkumu kontroles grupā ievērojami samazināja Mqf - par (7 \pm 10 \%).

Zinātnieki jau vairākus gadus ir izmantojuši šo integrējošo fiziologijas pieeju, mēgénot pētīt spēka treniņu ietekmi uz onkologisko pacientu kaheksijas 
mazināšanu (Battaglini et al., 2007), (Lira et al., 2011). Svarīgi, ka ir novērota un dokumentēta fiziskās slodzes pozitīvā ietekme uz olbaltumvielu sintēzi skeleta muskuḷos, palielinot pretiekaisuma citokīnu daudzumu - interleikīna-1 receptora antagonistu (IL- 1RA), interleikīnu 4 (IL-4), interleikīnu 10 (IL-10), interleikīnu 15 (IL-15), audzēja nekrozes faktora receptorus (sTNFR), šḳistošāà IL-6 receptoru (sIL6R) - un veicinot mioplastiskuma paātrināšanos (t. i., olbaltumvielu sintēzi) skeleta muskuḷos (Kim et al., 2015), (Suzuki, 2018). Šis pētījums apstiprina, ka KV pacientes var iesaistīties regulāros spēka treniņos un ka spēka treniņš var mainīt olbaltumvielu maiņas līdzsvaru, uzlabojot anaboliskos procesus un mazinot katabolisma stāvokli (Montalvo et al., 2018). Tas nozīmē, ka atbilstošs spēka treniņu daudzums nodrošina muskuḷu masas saglabāšanu vai pat tās pieaugumu adjuvantas terapijas laikā.

Tomēr tikai daži pētījumi ir spējuši pierādīt spēka treniņu ietekmi uz muskuļu masu pretvēža ārstēšanas laikā (Christensen et al., 2018). Svarīgi, ka muskuḷu adaptācija vispirms notiek nervu sistēmas līmen̄i, pirms sākas morfologiskas izmainas, kas ir atkarīgas no olbaltumvielu sintēzes un miofibilārās transformācijas, tādējādi tam nepieciešams salīdzinoši ilgāks adaptācijas periods (Folland and Williams, 2007). Kā iepriekš aprakstīts un parasti novērots KV pacientēm pēc pretvēža terapijas, arī šajā pētījumā kontroles grupā konstatēja Mqf samazināšanos, kas liecina, ka muskuḷu masas samazinājums ir viens no galvenajiem iemesliem apakšējo ekstremitāšu maksimālā muskuḷu spēka kritumam. Patiešām, pētījuma rezultāti atklāja, ka izmaiņas Mqf ir saistītas ar izmaiņām apakšējo ekstremitāšu maksimālajā muskuḷu spēkā. Tādējādi lielākā daḷa pētījumu, kuros izmanto spēka treniṇa metodes onkologiskajiem pacientiem, ir salīdzinoši īsi ( $<3$ mēneši), kas norāda: kaut gan morfologiskās adaptācijas laiks varētu būt nepietiekams, lai novērotu noteiktu adaptāciju, tomēr tas varētu būt pietiekams nervu sistēmas adaptācijai (Egan and Zierath, 2013). Lai gan MST primārais uzsvars ir uz nervu sistēmas 
adaptācijas izmaiņām un tam ir relatīvi zems metaboliskais stress, šajā pētījumā MST grupā tika konstatêts, ka MST ir nodrošinājis pietiekamu stimulu, lai saglabātu Mqf. Iegūtos rezultātus apstiprina nesen veiktais pētījums senioriem, kurā dokumentēta MST ietekme uz muskuḷu hipertrofiju, kas ir līdzīga ierastā (hipertrofijas) spēka treniņa laikā, veicot 10-12 atkārtojumus ar mērenu intensitāti (70-75 \% 1AM) (Wang et al., 2017). Iegūtie rezultāti veiktajā pētījumā parāda un apstiprina iepriekšējo pētījumu rezultātus, ka MST primāri stimulē nervu sistēmu, un papildina, ka adjuvantas terapijas laikā iespējams saglabāt muskuḷu masu. KV pacientes adjuvantas ķīmijterapijas laikā, izmantojot augstāku spēka treniņu intensitāti, var sasniegt gan nervu sistēmas, gan muskuḷu morfoloğisko adaptāciju.

Savukārt spēka treniņa trūkums kontroles grupā izraisīja muskuḷu masas samazināšanos, kur Mqf samazinājās par $(7 \pm 10 \%)$, $(\mathrm{p}<0,001)$. Jauniegūtie rezultāti apstiprina, ka ķīmijterapija veicina muskuḷu šķiedru samazināšanos, izraisot smagu skeleta muskuḷu sarkopēniju (Guigni et al., 2018). Muskuḷu masas samazināšanās var palielināt ḳimijterapijas toksicitāti, kas savukārt var izraisīt nepieciešamību samazināt tās devu vai atlikt ḳīmijterapijas kursu (Prado et al., 2011). Patiesi būtisks ir novērojums, ka pacientes, kuras turpina būt fiziski aktīvas pretvēža ārstēšanas laikā un nedēḷas plānā ietver spēka treniņus, var labāk izturēt un optimizēt ārstēšanas efektivitāti, kā arī daudz ātrāk pēc ārstēšanas pabeigšanas atgūt iepriekšējo fizisko spēju līmeni (Segal et al., 2003), (Campbell et al., 2012), (Courneya et al., 2014). Šie novērojumi apstiprina spēka treniņu nozīmi pretvēža ārstēšanas laikā. Pacientes, kurām diagnosticēts $K V$, bieži samazina ikdienas fizisko aktivitāšu daudzumu, kas pastiprina ārstēšanas blaknes, piemēram, sāpes, nogurumu, kardiotoksicitāti. Informācijas trūkuma dēl nenotiek ārstu un KV pacienšu dialogs un trūkst pamudinājuma palikt fiziski aktīvām ārstēšanas laikā, kas varētu mazināt ārstēšanas un neaktivitātes nelabvēlīgās sekas (Christensen et al., 2014). Līdz ar to dialoga veidošana starp 
ārstiem un pacientiem ir svarīgs solis, lai veicinātu izpratni par spēka treniņu nozīmi ārstēšanas laikā, šādi iedrošinot saglabāt noteiktu fizisko aktivitāšu līmeni un laikus uzsākot rehabilitācijas procesu.

\subsection{Funkcionālās spējas}

Pēc 12 nedēḷ ilga MST būtiski uzlabojās pacientu funkcionālās spējas, uzlabojot rezultātus standartizētos funkcionālajos testos. Turpretī kontroles grupā, kas neveica efektīvu spēka treniņu, izteikti samazinājās funkcionālo testu rezultāti un būtiski samazinājās funkcionālās spējas, kas tieši ietekmē ikdienas aktivitātes. Iegūtie rezultāti apstiprina, ka muskuḷu spēka un masas zudums pretvēža terapijas laikā atspoguḷojas ikdienas funkcionālajos uzdevumos, tādējādi nelabvēlīgi ietekmējot DzK. Tā kā lielākā daḷa smagumu nesošo aktivitāšu veic, izmantojot apakšejās ekstremitātes, spēka treniniiem apakšējām ekstremitātēm ārstēšanas laikā var būt īpaši praktisks efekts KV pacienšu veselībā. Šim nolūkam spēka treniņš apakšējām ekstremitātēm, nodarbinot vairākas locītavas un muskuḷu grupu, var būt vienkārša un efektīva stratēgeija, lai uzlabotu šo muskuḷu grupu spēku un spēka attīstīšanas ātrumu (RFD).

\subsection{Maksimāla spēka treniņi uzlabo fiziskā darba ekonomiju}

Pēc 24 MST sesijām tika novēra fiziskā darba ekonomijas (noteikta kā iešana uz skrejceḷa ar noteiktu submaksimālu slodzi) uzlabošanās, būtiski samazinot sirdsdarbības frekvenci submaksimālas slodzes laikā. Maksimālā muskuḷu spēka pieaugums KV pacientēm pozitīvi ietekmē aerobās spējas, uzlabojot vienu no galvenajiem aerobo spēju pamatkomponentiem - fiziskā darba ekonomiju (work economy).

Vairākos iepriekšējos pētījumos ir konstatēts, ka MST uzlabo fiziskā darba ekonomiju (Barrett-O'Keefe et al., 2012), (Wang et al., 2017), (Berg et al., 2018), un mūsu pētījums atbalsta šos rezultātus, papildinot, ka MST var efektīvi 
uzlabot darba ekonomiju arī KV pacientēm, ko mēra submaksimālās iešanas laikā. Svarīgi ir tas, ka treniņu apmeklētība bija augsta, norādot, ka MST ir pieḷaujams un izpildāms. Turklāt šajā pētījumā uzlabotā fiziskā darba ekonomija pozitīvi korelē ar palielinātu muskuḷ spēku. Tas atbilst Wang et al. (Wang et al., 2010) novērojumiem, apstiprinot mūsu rezultātus, ka fiziskā darba ekonomijas uzlabojumi patiešām ir saistīti ar lielāku muskuḷu spēku.

Ikdienas aktivitātes bieži tiek veiktas noteiktā intensitātē un ilgākā laikposmā. Tā kā lielākā daḷa ikdienas aktivitāšu tiek veiktas ar vieglu vai vidēji augstu intensitāti, maksimālais skābekḷa patēriņš $\left(\mathrm{VO}_{2 \max }\right)$ reti tiek sasniegts (Støren et al., 2008). Tomēr $\mathrm{VO}_{2 \max }$ neaktivitātes vai veselības problēmu dēl vienkāršu ikdienas darbu veikšana var kḷūt arvien sarežğîtāka vai var nākties samazināt to veikšanas intensitāti un aktivitāšu daudzumu (Støren et al., 2008). Turklāt onkologijas un novecošanas procesa rezultātā (Knaggs et al., 2011) palielinās energijjas patēriņš ikdienas aktivitāšu veikšanai, vēl vairāk veicinot CRF.

Uzlabojumi fiziskā darba ekonomijā sekmēja rezultātu uzlabojumus funkcionālajos testos (6MWD; pakāpienu tests; piecelšanās un apsēšanās tests; laiks līdz nogurumam) un papildina kopējos novērojumus, ka krūts vēža pacientes MST grupā ne tikai spēja novērst tipiski novēroto funkcionālo spēju samazināšanos, bet arī varēja uzlabot funkcionālās spējas ārstěšanās laikā tāpat, kā cilvēki bez sarežğītām veselības problēmām.

Turpretim kontroles grupai samazinājās fiziskā darba ekonomija. To palīdz izskaidrot pētījumi, kuros secināts, ka par agrīnu muskuḷu spēka zudumu, tos pienācīgi nenoslogojot, ir atbildīgi nervu sistēmas mehānismi. To apstiprina Deschenes et al. (2002) pētījums, ka pēc divu nedēḷu ilgas labās kājas imobilizācijas vieglā ortopēdiskā ceḷgala ortozē sešiem studentiem un četrām studentēm muskuḷu spēks samazinājās par $10 \%$, spēka attīstības ātrums (RFD) samazinājās par $17 \%$ Quadriceps muskulī, ko novērtēja, izmantojot 
elektromiogrāfijas ierakstus un muskuḷu biopsiju, kā arī novērtējot kopējo veikto darbu. Rezultāti apstiprina, ka spēka zudumu galvenokārt var saistīt ar samazinātu nervu sistēmas spēju aktivizēt muskuḷus (Deschenes et al., 2002).

Izmaiņas muskuḷos, kas rodas samazinātas fiziskās aktivitātes dēl, samazina muskuḷu izturību (aerobās spējas). Šīs izmaiņas samazina asins piegādi mazāk aktīviem muskuḷiem, kas rezultējas ar samazinātu kapilāru blīvumu, kas savukārt pasliktina glikozes transportu un substrātu pieejamību, mazāku mitohondrija blīvumu un samazinātu oksidatīvo enzīmu aktivitāti, šīs nelabvēlīgās izmaiṇas arī samazina muskuḷu spēju ǵenerēt spēku (Thompson, 2002). Fiziologiskā adaptācija fizisko aktivitāšu trūkuma rezultātā notiek ātri, un ir konstatēts, ka pirmajā imobilizācijas nedēḷā muskuḷu spēks samazinās par aptuveni 4 \% katru dienu (Suetta et al., 2004). Turklāt ir pierādīts, ka muskuḷu spēks samazinās no 25 līdz 30 \% pēc 6 nedēlu ilga gultas režīma (Berg et al., 1997).

Darba ekonomija ir galvenais aerobo spēju noteicošais faktors. Reālajā dzīvē aerobās spējas var būt diapazonā no profesionālām sacensībām ar augstu veiktspēju līdz ikdienas aktivitātēm pacientiem ar ierobežotām fiziskajām spējām. Onkologiskajiem pacientiem darba ekonomijas rādītāji, visticamāk, ir tādā līmen̄i, kas sagādā grūtības veikt ikdienas darbības un var būtiski samazināt ar veselību saistîto dzīves kvalitāti. Iegūtie rezultāti no veiktā pētījuma aktualizē MST iekḷaušanu onkologijas pacienu ārstēšanās procesā, jo īpaši pievēršot uzmanību izmantotajai intensitātei un eksplozīvai kustībai koncentriskajā fāzē, lai optimāli uzlabotu fiziskā darba ekonomiju. Pēc MST fiziskā darba ekonomija uzlabojās par 9 \%. Citiem vārdiem sakot, persona tagad spēj veikt lielāku darbu vai veikt tādu pašu darba apjomu ar mazāku piepūli, kā novērots šajā pētījumā, kur iešana ar 40 vatu slodzi tagad prasa mazāk enerǵijas. Savukārt 4 \% samazinājums darba ekonomijā kontroles grupai tagad prasa vairāk enerǵijas ar to pašu submaksimālo slodzi, kas pielīdzināma ikdienas aktivitāšu veikšanai. 


\subsection{Augstas intensitātes spēka treniṇu programmas tolerance}

Lai gan MST var uzskatīt par fiziski grūtu, fakts, ka pētījuma apmeklētības rādītājs ir 96 \%, liecina, ka KV pacientes, neraugoties uz adjuvantas terapijas agrīnās fāzes blaknēm, spēj veikt apakšējo ekstremitāšu spēka treniņus ar noteikti intensitāti 90 \% 1AM. Turklāt intervences laikā netika novērotas traumas un apgrūtinājumi, kas apstiprina, ka pārraudzītas MST nodarbības ir iespējamas un drošas KV ārstēšanas laikā.

No drošības viedokḷa un traumu riska, veicot MST, lielāka slodze ir kustības koncentriskajā fâzē. Kustības ekscentriskā fāze, kas ir vairāk saistīta ar lielāku muskuḷu noslodzi un mikrotraumām (Toien et al., 2018), tiek veikta lēni un kontrolēti, līdz ar to MST ir salīdzinoši drošs un īstenojams pat ar augstu intensitāti. Tas ir svarīgs aspekts, jo tiek novērsts liela trieciena spēks, kas saistīts ar ekscentrisko muskuḷu darbību (piemēram, lēciens) (Toien et al., 2018). Tomēr ir svarīgi koncentrisko fāzi veikt ar maksimālu spēka mobilizāciju (censties svaru pacelt, cik ātri vien iespējams), lai palielinātu nervu sistēmas stimulāciju (Behm and Sale, 1993). Šo procesu ir svarīgi ievērot, ņemot vērā, ka pētījuma dalībnieces nav uzskatāmas par labi trenētām pirms pētījuma uzsākšanas, lai maksimāli mazinātu traumu risku.

Visas treniņu sesijas tika izpildītas atbilstoši pētījuma protokolam, un treniņu sesijās tika sasniegta nepieciešamā (progresējoša) intensitāte. Iekḷautās pacientes noslēdza līdzdalību pētījumā, un MST laikā netika novērotas traumas vai blaknes.

\subsection{Dzives kvalitāte, kas saistīta ar veselību}

DzK ir daḷa no objektīvās dzīves kvalitātes un attiecas uz tām dzīves kvalitātes daḷām, kuru pamatā ir veselības stāvoklis vai kuras tieši vai netieši ietekmē veselības stāvoklis (ārstēšanas blaknes, fiziskā, kognitīvā, emocionālā 
un sociālā veselība u. c.), un šajā aspektā DzK pārklājas ar veselības stāvokḷa jēdzienu (Karimi and Brazier, 2016). DzK ir fiziskāa, garīgāa, sociālā un funkcionālā veselība atbilstoši personas priekšstatam par to, un tā vienlīdz ietilpst visās šajās atšķirīgajās jomās, tādējādi vispārējais mērkis fizisko aktivitāšu pêtījumiem onkolog̣ijā ir vērsts uz dažādiem fizioloǵiskajiem rezultātiem, lai uzlabotu pacienta DzK.

Rezultāti šajā pētîjumā parāda, ka 12 nedēḷu ilgs MST veicināja vispārējā veselības stāvokḷa/QoL (QoL) uzlabošanos par 13 \% MST grupā, bet kontroles grupā netika novērotas būtiskas izmaiņas. Turklāt intervences periods MST grupai sekmēja uzlabojumus lomu izpildē par $23 \%$, emocionālajā labsajūtā par $13 \%$, sociālajos aspektos par $12 \%$ un vienlaikus samazināja CRF par $24 \%$. Tādējādi spēka treniņu labvēlīgā ietekme uz noguruma samazināšanos ir ne tikai statistiski, bet arī klīniski nozīmīga, jo daudzas KV pacientes sajūt nogurumu kā visvairāk traucējošo sistēmiskas terapijas blakni (Berger et al., 2012).

Līdzīgi mūsu pētījuma rezultātiem, arī van Waart et al. (van Waart et al., 2015b) pētījums, kas ietvēra vidējas un augstas intensitātes aerobās izturības treniņus un spēka treniņus ar progresējoši intensitāti, parādīja, ka kombinētā vingrojumu programma ir efektīva, lai mazinātu CRF. Turpretim citā pêtījumā Mutrie et al. (Mutrie et al., 2007) netika konstatētas CRF atšķirības starp dalībniekiem, kas veica kombinētus aerobās slodzes un spēka treniṇus ar vidēju intensitāti, salīdzinot ar kontroles grupu, secinot, ka ir nepieciešama augstāka intensitāte/slodze, lai novērstu CRF palielināšanos, un ka treniņu multimodalitāte var traucēt tipiskiem fiziologiskiem adaptācijas procesiem, ko nodrošina tikai spēka treniņš. Tā kā mūsu pētījumā uzmanība bija pievērsta tikai spēka treniniem bez aerobās izturības treniniem, mūsu rezultāti liecina, ka MST ir efektīvs veids, kas ievērojami samazina nogurumu, pateicoties saglabātai muskuḷu masai, lielākam muskuḷu spēkam un funkcionālajām spējām. 
Jānorāda, ka kontroles grupā CRF kḷuva izteiktāks par $25 \%$ pēc intervences perioda. Tas skaidri parāda, cik nopietni slimība un ārstēšana bez spēka treniņiem ietekmē produktivitāti, brīvā laika aktivitātes, ǵimenes dzīvi un attiecības ar draugiem, - šādā gadījumā visas minētās sociāli un emocionāli svarīgās darbības prasītu lielāku piepūli. Škiet, ka intensitāte ir svarīga, ne tikai lai uzlabotu CRF, bet arī lai uzlabotu DzK. Courneya et al. pētījumā (Courneya et al., 2007b) multimodālo treniņu intervence uzlaboja fiziskās spējas, bet neuzlaboja DzK, parādot, ka spēka treniṇi ar intensitāti (60-70 \% aprēḳinātā 1AM) nav pietiekami un nenodrošina vēlamo intensitāti un $70 \%$ treninuu apmeklētība samazināja kopējo treniņu apjomu. Turpretim $96 \%$ treniņu apmeklētība mūsu pētījumā ievērojami pārsniedz parasti novēroto līdzdalības līmeni fizisko aktivitāšu pētījumos (Rejeski et al., 2007); tas papildina iepriekš minēto, ka augsta intensitāte veicina lielu spēka pieaugumu un tā būtiski uzlabo CRF un DzK, neraugoties uz vienlaikus saņemto sistēmisko terapiju. Mūsu pētījumā KV pacientes apmeklēja MST ar teicamu līdzdalību. Turklāt MST tika uzsākts pēc iespējas ātri, un pirms pirmā ķ̣̄mijterapijas kursa pacientes jau bija iepazinušas treniņu procesu, kā arī jau pakāpeniski ieguva muskuḷu spēka pieaugumu. Iespējams, šāda veida taktika no pētījuma autora puses bija sekmīga, kas motivēja pacientes regulāri apmeklēt MST.

Pamatojoties uz pētījuma autora pieredzi un zināšanām, šis ir pirmais pētījums, kurā pierādīta MST ietekme uz lomu izpildi, sociālo aspektu un emocionālo labsajūtu KV pacientēm ķīmijterapijas laikā, izmantojot dzīves kvalitātes mērījumu anketu EORTC QLQ-C30. Iegūtos rezultātus varētu skaidrot, ka iesaistīšanās uzraudzītā fizisko aktivitāšu programmā var uzlabot gan lomu, gan emocionālo funkciju un šāda pozitīva mijiedarbība var potenciāli sniegt manāmus uzlabojumus (McAuley et al., 2000). Šajā pētījumā treniņu process tika organizēts nelielās grupās pa 3-5 pacientēm, tādēl tādi faktori kā sociālais atbalsts no treniņu biedrenēm, sarunas ar citiem onkologiskajiem 
pacientiem, došanās uz treniņu norises vietu divas reizes nedēḷā un pozitīvas attieksmes saglabāšana, kḷūstot proaktīvai, var sniegt papildu nozīmi novērotajiem uzlabojumiem. Pakāpeniski turpinot treniņu procesu, paaugstinās neatkarības līmenis, un tas ir viens no svarīgākajiem mehānismiem, kas sekmē emocionālo labsajūtu (McAuley et al., 2000), mūsu pētījumā paaugstināts neatkarības līmenis var būt saistîts ar sajūtām un spēju veikt MST, tādā veidā pozitīvi ietekmējot līdzdalību ikdienas aktivitātēs. Turklāt EORTC QLQ-BR23 anketas rezultāti liecināja, ka kontroles grupā ir pasliktinājušās sistēmiskās terapijas blaknes un priekšstats par sava ķermeņa uztveri, bet šo skalu izmaiṇas MST grupā netika novērotas.

Vēža diagnoze cilvēkam ir īpaši sarežǵīts dzīves posms. MST ir iedarbīga metode, kas KV pacientēm agrīnā pretvēža terapijas posmā palīdz uzlabot DzK un samazināt CRF. Lai gan Amerikas Sporta medicīnas koledžas un Amerikas Vēža biedrības pamatnostādnes rekomendācijās ietver spēka treniņus, tomēr šīs programmas galvenokārt koncentrējas uz aerobās slodzes treniņu metodiku. Tāpēc šā pētījuma rezultāti lieliski papildina to, ka spēka treniņu veikšana ir efektīva un svarīga papildus aerobās slodzes treniņiem. Nozīmīgi, ka mūsu rezultāti apliecina to, ka MST efektīvi darbojas ne tikai fiziskajā aspektā, bet arī psihosociālajā aspektā, tā pozitīvi ietekmējot DzK.

\subsection{Pētījuma priekšrocības un ierobežojumi}

Tikai daži pētījumi ir apskatījuši spēka treniņu ietekmi KV ārstēšanas sākumposmā ar mainīgiem rezultātiem. Šā pētījuma priekšrocība ir efektîva augstas intensitātes spēka treniņa metodoloğijas piemērošana funkcionāli nozīmīgām apakšējo ekstremitāšu muskuḷu grupām. MST ir laika un izmaksu ziņā efektīvs veids, treniņu process nedẹḷā prasa mazāk par stundu, un vienā treniņa sesijā pacienti var trenēties grupās pa 3-5 personām, izmantojot vienu trenažieri. Kaut arī adjuvantas terapijas agrīnajā fāzē ir jau novērojamas terapijas 
blaknes, pacienšu līdzdalības līmenis pētījumā bija 96 \%, kas liecina, ka šajā kritiskajā KV ārstēšanas posmā MST, izmantojot trenažieri spiešanai ar kājām, ir izpildāms. Svarīgi, ka spēka treniņu laikā netika novērotas traumas. Kopumā šā pētījuma galvenais ieguvums ir šāds: muskuḷu spēka pieaugums apakšējām ekstremitātēm sekmēja funkcionālo spēju uzlabošanos, kā arī samazināja CRF un uzlaboja DzK.

Viens no šā pētījuma trūkumiem ir nervu impulsa pārvades ātruma mērīšana un muskuḷu komponentu (morfolog̣ijas, spēka attīstības ātrums) mērījumu trūkums. Šie papildu mērījumi varētu sniegt svarīgu informāciju par to, kāda ir spēka treniņu uzlabojumu izcelsme un vai noteiktas adjuvantas terapijas sastāvdalias, iespējams, ietekmēja dažus faktorus (spēka pieauguma) vairāk nekā citus. Tā kā KV pacientēm bieži novēro kaulu minerālu blīvuma samazināšanos, būtu bijis lietderīgi iekḷaut muskuloskeletālos mērījumus. Iepriekš veiktos pētījumos ir apstiprināts, ka palielināta apakšējo ekstremitāšu muskuḷu spēka rezultātā uzlabojas kaulu osifikācija un kaulu minerālvielu blīvums (Nygard et al., 2018), un būtu bijis svarīgi izpētît, vai tas iespējams arī KV ārstēšanas kontekstā. Visbeidzot, arī salīdzinoši īsais pētījuma laiks ir ierobežojums, jo informācija par ilgtermiņa ietekmi būtu nodrošinājusi labāku izpratni par fizisko aktivitāšu nozīmi krūts vēža ārstēšanā un ietekmi uz dzīvildzi.

\subsection{Klīniskā nozīme onkoloğijas pacientu rehabilitācijāa}

Šis pētījums parāda, cik svarīgi ir novērst adjuvantas terapijas kaitīgo ietekmi uz neiromuskulāro funkciju. Maksimālā spēka treniņš krūts vēža pacientēm, izmantojot trenažieri spiešanai ar kājām, uzlaboja apakšējo ekstremitāšu maksimālo muskuḷu spēku, fiziskā darba ekonomiju, funkcionālās spējas, saglabāja muskuḷu masu un paaugstināja DzK, savukārt kontroles grupā tika novērots visu šo main̄̄go lielumu samazinājums. Līdz ar to 20 minūšu MST divas reizes nedēẹā, izmantojot vienu vingrinājumu (dinamiskā spiešana, 
izmantojot trenažieri spiešanai ar kājām), ir pietiekami, lai paaugstinātu apakšējo ekstremitāšu maksimālo muskuḷu spēku un funkcionālās spējas. Netika novērotas traumas treniņu periodā. Lai gan būtu lietderīgi pievienot spēka treniņus arī citu muskuḷu grupām, ievērojot augstākas intensitātes principu, apakšējās ekstremitātes tika noteiktas par prioritāti, jo tās veic svaru nesošās funkcijas, kā arī augšējās ekstremitātes ir pakḷautas lielam komplikāciju riskam pēcoperācijas periodā. Konstatētie fakti pētījuma ietvaros pamato iepriekšējos apgalvojumus un rezultātus par spēka treniņu ieviešanu adjuvantas KV ārstēšanas laikā, iedrošinot rehabilitācijas speciālistu izmantot augstāku intensitāti apakšējām ekstremitātēm. Ārstēšanas laikā integrējot augstākas intensitātes spēka treniņu metodologiiju, atbilstoši jāsagatavo personāls, lai pārraudzītu nodarbības. Spēka treniniem ar progresīvu slodzes intensitāti jābūt pieejamiem, un tie būtu jāveic pēc iespējas ātrāk pēc KV diagnozes noteikšanas, lai saglabātu vai pat uzlabotu DzK. 


\section{Secinājumi}

1. Trīs mēnešus ilgs MST, izmantojot trenažieri spiešanai ar kājām, ir efektīva, droša, iespējama un izpildāma metode, lai paaugstinātu maksimālo muskuḷu spēku KV pacientēm ārstēšanas laikā.

2. Spēka treniṇu uzsākšana agrīnā krūts vēža ārstēšanas posmā var novērst muskuḷu masas samazināšanos, jo maksimālā spēka treniņš nodrošina pietiekamu stimulu, lai krūts vēža pacientēm adjuvantas terapijas laikā saglabātu muskuḷu masu.

3. Paaugstināts apakšējo ekstremitāšu maksimālais muskuḷu spēks KV pacientēm ārstēšanas laikā sekmē aerobo spēju paaugstināšanos uzlabojot fiziskā darba ekonomiju.

4. MST funkcionāli nozīmīgajām apakšèjām ekstremitātēm paaugstina funkcionālās spējas.

5. Maksimālā spēka treniṇi veicināja ar veselību saistītās dzīves kvalitātes uzlabošanos, mazinot nogurumu, uzlabojot vispārējo veselības stāvokli, kā arī sociālos faktorus, emocionālo pašsajūtu, un atviegloja ārstēšanas blaknes.

Šie rezultāti liecina, ka apakšējo ekstremitāšu augstas intensitātes spēka treniņi būtu jāietver KV ārstēšanā, ne tikai lai laikposmā pēc diagnozes neitralizētu parasti novēroto apakšējo ekstremitāšu muskuḷu spēka samazināšanos, bet arī lai uzlabotu fizisko veselību, funkcionalitāti un DzK. 


\section{Publikācijas par pētījuma tēmu}

\section{Zinātniskie raksti}

1. Heavy resistance training in breast cancer patients undergoing adjuvant therapy.

Ceseiko, R., Thomsen, S. N., Tomsone, S., Eglitis, J., Vetra, A., Srebnijs, A., Timofejevs, M., Purmalis, E., Wang, E. (2020). Heavy Resistance Training in Breast Cancer Patients Undergoing Adjuvant Therapy. Medicine and Science in Sports and Exercise, 2020;52(6):1239-1247.

2. The impact of maximal strength training on quality of life among women with breast cancer undergoing treatment.

Ceseiko, R., Eglitis, J., Srebnijs, A., Timofejevs, M., Purmalis, E., Erts, R., Vetra, A., Tomsone, S. (2019). The impact of maximal strength training on quality of life among women with breast cancer undergoing treatment. Experimental Oncology, 41(2), 166-172.

\section{Tēzes un prezentācijas starptautiskās konferencēs}

1. Ceseiko, R. (2017). 84P - Effective strength training for breast cancer patients: a literature review. Annals of Oncology, 28, x23. doi:https://doi.org/10.1093/annonc/mdx655.026. ESMO Asia 2017 Congress, Singapore, Singapore, 17/11/2017-19/11/2017 (Stenda referāts).

2. Ceseiko, R., Tomsone, S., Srebnijs, A., Vetra, A., Timofejevs, M., Purmalis, E. \& Eglītis, J. (2018). Maximal Strength Training for Breast Cancer Patients Undergoing Adjuvant Treatment. Journal of Global Oncology, 4 (Supplement 2), 102s-102s. doi:10.1200/jgo.18.29400. World Cancer Congress held in Kuala Lumpur, Malaysia from 1 - 4 October 2018 (Mutvārdu prezentācija). 


\section{Tēzes un prezentācijas vietēja mēroga konferencēs Latvijā}

1. Cešeiko, R., Eglītis, J., Vētra, A., Tomsone, S. Efektīvas spēka treniņa metodes krūts vēža pacientēm: literatūras pārskats. Rīgas Stradinna universitātes 2018. gada zinātniskā konference, Rīga, Latvija, tēžu grāmata: 119 (Mutvārdu prezentācija).

2. Cešeiko, R., Eglītis, J., Srebnijs, A., Timofejevs, M., Purmalis, E., Tomsone, S. Krūts vēža slimnieču aerobās spējas pirms ķīmijterapijas uzsākšanas. Rīgas Stradiṇa universitātes 2018. gada zinātniskā konference, Rīga, Latvija, tēžu grāmata: 97 (Mutvārdu prezentācija).

3. Ceseiko, R., Eglitis, J., Srebnijs, A., Timofejevs, M., Purmalis, E., Vetra, A., Tomsone, S. Maximal strength training for breast cancer patients undergoing adjuvant treatment. Rīga Stradiņš University international conference "Knowledge For Use In Practice", 2019. gada 1.-3. aprīlis, Rīga, Latvija, tēžu grāmata: 52 (Stenda referāts). 


\section{Literatūras saraksts}

1. Al-Majid, S. and McCarthy, D. O. (2001). Cancer-induced fatigue and skeletal muscle wasting: the role of exercise. Biol Res Nurs 2, 186-197.

2. Barrett-O'Keefe, Z., Helgerud, J., Wagner, P. D. and Richardson, R. S. (2012). Maximal strength training and increased work efficiency: contribution from the trained muscle bed. Journal of applied physiology (Bethesda, Md : 1985) 113, 18461851 .

3. Battaglini, C., Bottaro, M., Dennehy, C., Rae, L., Shields, E., Kirk, D. and Hackney, A. C. (2007). The effects of an individualized exercise intervention on body composition in breast cancer patients undergoing treatment. Sao Paulo Med J 125, $22-28$.

4. Battaglini, C. L., Hackney, A. C. and Goodwin, M. L. (2012). Cancer cachexia: muscle physiology and exercise training. Cancers (Basel) 4, 1247-1251.

5. Battaglini, C. L., Mills, R. C., Phillips, B. L., Lee, J. T., Story, C. E., Nascimento, M. G. and Hackney, A. C. (2014). Twenty-five years of research on the effects of exercise training in breast cancer survivors: A systematic review of the literature. World journal of clinical oncology 5, 177-190.

6. Behm, D. G. and Sale, D. G. (1993). Intended rather than actual movement velocity determines velocity-specific training response. Journal of applied physiology (Bethesda, Md : 1985) 74, 359-368.

7. Berg, H. E., Larsson, L. and Tesch, P. A. (1997). Lower limb skeletal muscle function after 6 wk of bed rest. J Appl Physiol (1985) 82, 182-188.

8. Berg, O. K., Nyberg, S. K., Windedal, T. M. and Wang, E. (2018). Maximal strength training-induced improvements in forearm work efficiency are associated with reduced blood flow. Am J Physiol Heart Circ Physiol 314, H853-h862.

9. Berger, A. M., Gerber, L. H. and Mayer, D. K. (2012). Cancer-related fatigue: implications for breast cancer survivors. Cancer 118, 2261-2269.

10. Bray, F., Ferlay, J., Soerjomataram, I., Siegel, R. L., Torre, L. A. and Jemal, A. (2018). Global cancer statistics 2018: GLOBOCAN estimates of incidence and mortality worldwide for 36 cancers in 185 countries. CA Cancer J Clin 68, 394-424.

11. Buffart, L. M., Sweegers, M. G., de Ruijter, C. J., Konings, I. R., Verheul, H. M., van Zweeden, A. A., Grootscholten, C., Chinapaw, M. J. and Altenburg, T. M. (2020). Muscle contractile properties of cancer patients receiving chemotherapy: Assessment of feasibility and exercise effects. Scandinavian Journal of Medicine \& Science in Sports 30, 1918-1929.

12. Burckart, K., Beca, S., Urban, R. J. and Sheffield-Moore, M. (2010). Pathogenesis of muscle wasting in cancer cachexia: targeted anabolic and anticatabolic therapies. Curr Opin Clin Nutr Metab Care 13, 410-416. 
13. Campbell, K. L., Neil, S. E. and Winters-Stone, K. M. (2012). Review of exercise studies in breast cancer survivors: attention to principles of exercise training. $\mathrm{Br} \mathrm{J}$ Sports Med 46, 909-916.

14. Cheema, B., Gaul, C. A., Lane, K. and Fiatarone Singh, M. A. (2008). Progressive resistance training in breast cancer: a systematic review of clinical trials. Breast cancer research and treatment 109, 9-26.

15. Christensen, J. F., Jones, L. W., Andersen, J. L., Daugaard, G., Rorth, M. and Hojman, P. (2014). Muscle dysfunction in cancer patients. Ann Oncol 25, 947-958.

16. Christensen, J. F., Simonsen, C. and Hojman, P. (2018). Exercise Training in Cancer Control and Treatment. Compr Physiol 9, 165-205.

17. Cornette, T., Vincent, F., Mandigout, S., Antonini, M.-T., Leobon, S., Labrunie, A., Venat, L., Lavau-Denes, S. and Tubiana-Mathieu, N. (2016). Effects of home-based exercise training on VO2 in breast cancer patients under adjuvant or neoadjuvant chemotherapy (SAPA): a randomized controlled trial. European journal of physical and rehabilitation medicine 52, 223-232.

18. Courneya, K. S., Segal, R. J., Mackey, J. R., Gelmon, K., Reid, R. D., Friedenreich, C. M., Ladha, A. B., Proulx, C., Vallance, J. K. and Lane, K. (2007a). Effects of aerobic and resistance exercise in breast cancer patients receiving adjuvant chemotherapy: a multicenter randomized controlled trial. Journal of clinical oncology 25, 4396-4404.

19. Courneya, K. S., Segal, R. J., Mackey, J. R., Gelmon, K., Reid, R. D., Friedenreich, C. M., Ladha, A. B., Proulx, C., Vallance, J. K., Lane, K., et al. (2007b). Effects of aerobic and resistance exercise in breast cancer patients receiving adjuvant chemotherapy: a multicenter randomized controlled trial. J Clin Oncol 25, 4396- 4404.

20. Courneya, K. S., Segal, R. J., McKenzie, D. C., Dong, H., Gelmon, K., Friedenreich, C. M., Yasui, Y., Reid, R. D., Crawford, J. J. and Mackey, J. R. (2014). Effects of exercise during adjuvant chemotherapy on breast cancer outcomes. Medicine and science in sports and exercise 46, 1744-1751.

21. De Backer, I. C., van Breda, E., Vreugdenhil, A., Nijziel, M. R., Kester, A. D. and Schep, G. (2007). High-intensity strength training improves quality of life in cancer survivors. Acta oncologica (Stockholm, Sweden) 46, 1143-1151.

22. Deschenes, M. R., Giles, J. A., McCoy, R. W., Volek, J. S., Gomez, A. L. and Kraemer, W. J. (2002). Neural factors account for strength decrements observed after short-term muscle unloading. Am J Physiol Regul Integr Comp Physiol 282, R578-583.

23. Egan, B. and Zierath, J. R. (2013). Exercise metabolism and the molecular regulation of skeletal muscle adaptation. Cell metabolism 17, 162-184.

24. Endo, Y., Nourmahnad, A. and Sinha, I. (2020). Optimizing Skeletal Muscle Anabolic Response to Resistance Training in Aging. Frontiers in Physiology 11. 
25. Fairman, C. M., Hyde, P. N. and Focht, B. C. (2017). Resistance training interventions across the cancer control continuum: a systematic review of the implementation of resistance training principles. Br J Sports Med 51, 677-685.

26. Fanzani, A., Conraads, V. M., Penna, F. and Martinet, W. (2012). Molecular and cellular mechanisms of skeletal muscle atrophy: an update. J Cachexia Sarcopenia Muscle 3, 163-179.

27. Folland, J. P. and Williams, A. G. (2007). The adaptations to strength training: morphological and neurological contributions to increased strength. Sports Med 37, 145-168.

28. Guigni, B. A., Callahan, D. M., Tourville, T. W., Miller, M. S., Fiske, B., Voigt, T., Korwin-Mihavics, B., Anathy, V., Dittus, K. and Toth, M. J. (2018). Skeletal muscle atrophy and dysfunction in breast cancer patients: role for chemotherapy-derived oxidant stress. Am J Physiol Cell Physiol 315, C744-c756.

29. Hagstrom, A. D., Shorter, K. A. and Marshall, P. W. M. (2019). Changes in Unilateral Upper Limb Muscular Strength and Electromyographic Activity After a 16-Week Strength Training Intervention in Survivors of Breast Cancer. J Strength Cond Res 33, 225-233.

30. Heggelund, J., Fimland, M. S., Helgerud, J. and Hoff, J. (2013). Maximal strength training improves work economy, rate of force development and maximal strength more than conventional strength training. Eur J Appl Physiol 113, 1565-1573.

31. Helgerud, J., Karlsen, T., Kim, W. Y., Høydal, K. L., Støylen, A., Pedersen, H., Brix, L., Ringgaard, S., Kværness, J. and Hoff, J. (2011). Interval and strength training in CAD patients. Int J Sports Med 32, 54-59.

32. Hoff, J., Gran, A. and Helgerud, J. (2002). Maximal strength training improves aerobic endurance performance. Scandinavian journal of medicine \& science in sports $12,288-295$.

33. Hoff, J., Tjønna, A. E., Steinshamn, S., Høydal, M., Richardson, R. S. and Helgerud, J. (2007). Maximal strength training of the legs in COPD: a therapy for mechanical inefficiency. Med Sci Sports Exerc 39, 220-226.

34. Irwin, M. L., Crumley, D., McTiernan, A., Bernstein, L., Baumgartner, R., Gilliland, F. D., Kriska, A. and Ballard-Barbash, R. (2003). Physical activity levels before and after a diagnosis of breast carcinoma: the Health, Eating, Activity, and Lifestyle (HEAL) study. Cancer 97, 1746-1757.

35. Yakovenko, A., Cameron, M. and Trevino, J. G. (2018). Molecular therapeutic strategies targeting pancreatic cancer induced cachexia. World J Gastrointest Surg 10, 95-106.

36. Johns, N., Stephens, N. A. and Fearon, K. C. (2013). Muscle wasting in cancer. Int J Biochem Cell Biol 45, 2215-2229.

37. Karimi, M. and Brazier, J. (2016). Health, Health-Related Quality of Life and Quality of Life: What is the Difference? PharmacoEconomics 34, 645-649. 
38. Kim, H. K., Konishi, M., Takahashi, M., Tabata, H., Endo, N., Numao, S., Lee, S. K., Kim, Y. H., Suzuki, K. and Sakamoto, S. (2015). Effects of Acute Endurance Exercise Performed in the Morning and Evening on Inflammatory Cytokine and Metabolic Hormone Responses. PLoS One 10, e 0137567.

39. Klassen, O., Schmidt, M. E., Ulrich, C. M., Schneeweiss, A., Potthoff, K., Steindorf, K. and Wiskemann, J. (2017). Muscle strength in breast cancer patients receiving different treatment regimes. J Cachexia Sarcopenia Muscle 8, 305-316.

40. Knaggs, J. D., Larkin, K. A. and Manini, T. M. (2011). Metabolic cost of daily activities and effect of mobility impairment in older adults. Journal of the American Geriatrics Society 59, 2118-2123.

41. L.R.V.K (2018). Latvijas Republikas Valsts kontrole. Revīzijas ziņojums "Vai medicīniskā rehabilitācija tiek sniegta pacientiem, kam tā ir vajadz̄ìga, un pareizajā laikā?". Iegūts no: http://wwwlrvkgovlv/uploads/reviziju-zinojumi/2016/24144 2016/Revizijas\%20zinojums_Mediciniska\%20rehabilitacija_07122018pdf [sk. 24.02.2020].

42. Lindle, R. S., Metter, E. J., Lynch, N. A., Fleg, J. L., Fozard, J. L., Tobin, J., Roy, T. A. and Hurley, B. F. (1997). Age and gender comparisons of muscle strength in 654 women and men aged 20-93 yr. J Appl Physiol (1985) 83, 1581-1587.

43. Lira, F. S., Yamashita, A. S., Rosa, J. C., Tavares, F. L., Caperuto, E., Carnevali, L. C., Jr., Pimentel, G. D., Santos, R. V., Batista, M. L., Jr., Laviano, A., et al. (2011). Hypothalamic inflammation is reversed by endurance training in anorecticcachectic rats. Nutr Metab (Lond) 8, 60.

44. Mazzuca, F., Onesti, C. E., Roberto, M., Di Girolamo, M., Botticelli, A., Begini, P., Strigari, L., Marchetti, P. and Muscaritoli, M. (2018). Lean body mass wasting and toxicity in early breast cancer patients receiving anthracyclines. Oncotarget 9, 25714-25722.

45. McAuley, E., Blissmer, B., Katula, J., Duncan, T. E. and Mihalko, S. L. (2000). Physical activity, self-esteem and self-efficacy relationships in older adults: a randomized controlled trial. Annals of behavioral medicine : a publication of the Society of Behavioral Medicine 22, 131-139.

46. McTiernan, A., Friedenreich, C. M., Katzmarzyk, P. T., Powell, K. E., Macko, R., Buchner, D., Pescatello, L. S., Bloodgood, B., Tennant, B., Vaux-Bjerke, A., et al. (2019). Physical Activity in Cancer Prevention and Survival: A Systematic Review. Med Sci Sports Exerc 51, 1252-1261.

47. Mijwel, S., Backman, M., Bolam, K. A., Jervaeus, A., Sundberg, C. J., Margolin, S., Browall, M., Rundqvist, H. and Wengstrom, Y. (2018a). Adding high-intensity interval training to conventional training modalities: optimizing health-related outcomes during chemotherapy for breast cancer: the OptiTrain randomized controlled trial. Breast cancer research and treatment 168, 79-93.

48. Mijwel, S., Backman, M., Bolam, K. A., Olofsson, E., Norrbom, J., Bergh, J., Sundberg, C. J., Wengström, Y. and Rundqvist, H. (2018b). Highly favorable 
physiological responses to concurrent resistance and high-intensity interval training during chemotherapy: the OptiTrain breast cancer trial. Breast cancer research and treatment 169, 93-103.

49. Mijwel, S., Cardinale, D. A., Norrbom, J., Chapman, M., Ivarsson, N., Wengström, Y., Sundberg, C. J. and Rundqvist, H. (2018c). Exercise training during chemotherapy preserves skeletal muscle fiber area, capillarization and mitochondrial content in patients with breast cancer. Faseb j 32, 5495-5505.

50. Møller, T., Andersen, C., Lillelund, C., Bloomquist, K., Christensen, K. B., Ejlertsen, B., Tuxen, M., Oturai, P., Breitenstein, U., Kolind, C., et al. (2020). Physical deterioration and adaptive recovery in physically inactive breast cancer patients during adjuvant chemotherapy: a randomised controlled trial. Scientific Reports 10,9710 .

51. Montalvo, R. N., Hardee, J. P., VanderVeen, B. N. and Carson, J. A. (2018). Resistance Exercise's Ability to Reverse Cancer-Induced Anabolic Resistance. Exerc Sport Sci Rev 46, 247-253.

52. Moreland, J. D., Richardson, J. A., Goldsmith, C. H. and Clase, C. M. (2004). Muscle weakness and falls in older adults: a systematic review and meta-analysis. J Am Geriatr Soc 52, 1121-1129.

53. Mutrie, N., Campbell, A. M., Whyte, F., McConnachie, A., Emslie, C., Lee, L., Kearney, N., Walker, A. and Ritchie, D. (2007). Benefits of supervised group exercise programme for women being treated for early stage breast cancer: pragmatic randomised controlled trial. BMJ 334, 517-517.

54. Nygard, M., Mosti, M. P., Brose, L., Flemmen, G., Stunes, A. K., SorskarVenaes, A., Heggelund, J. and Wang, E. (2018). Maximal strength training improves musculoskeletal health in amphetamine users in clinical treatment. Osteoporosis international: a journal established as result of cooperation between the European Foundation for Osteoporosis and the National Osteoporosis Foundation of the USA 29, 2289-2298.

55. Prado, C. M., Antoun, S., Sawyer, M. B. and Baracos, V. E. (2011). Two faces of drug therapy in cancer: drug-related lean tissue loss and its adverse consequences to survival and toxicity. Current Opinion in Clinical Nutrition \& Metabolic Care 14, 250-254.

56. Rejeski, W. J., Miller, M. E., King, A. C., Studenski, S. A., Katula, J. A., Fielding, R. A., Glynn, N. W., Walkup, M. P., Ashmore, J. A. and Investigators, L. (2007). Predictors of adherence to physical activity in the Lifestyle Interventions and Independence for Elders pilot study (LIFE-P). Clin Interv Aging 2, 485-494.

57. Schmidt, T., Weisser, B., Duerkop, J., Jonat, W., van Mackelenbergh, M., Roecken, C. and Mundhenke, C. (2015). Comparing endurance and resistance training with standard care during chemotherapy for patients with primary breast cancer. Anticancer research 35, 5623-5629. 
58. Schmitz, K. H., Courneya, K. S., Matthews, C., Demark-Wahnefried, W., Galvao, D. A., Pinto, B. M., Irwin, M. L., Wolin, K. Y., Segal, R. J., Lucia, A., et al. (2010). American College of Sports Medicine roundtable on exercise guidelines for cancer survivors. Medicine and science in sports and exercise 42, 1409-1426.

59. Schwartz, A. L. and Winters-Stone, K. (2009). Effects of a 12-month randomized controlled trial of aerobic or resistance exercise during and following cancer treatment in women. The Physician and Sportsmedicine 37, 62-67.

60. Segal, R. J., Reid, R. D., Courneya, K. S., Malone, S. C., Parliament, M. B., Scott, C. G., Venner, P. M., Quinney, H. A., Jones, L. W., D'Angelo, M. E., et al. (2003). Resistance exercise in men receiving androgen deprivation therapy for prostate cancer. Journal of clinical oncology: official journal of the American Society of Clinical Oncology 21, 1653-1659.

61. Støren, O., Helgerud, J., Støa, E. M. and Hoff, J. (2008). Maximal strength training improves running economy in distance runners. Med Sci Sports Exerc 40, 1087- 1092.

62. Suetta, C., Magnusson, S. P., Rosted, A., Aagaard, P., Jakobsen, A. K., Larsen, L. H., Duus, B. and Kjaer, M. (2004). Resistance training in the early postoperative phase reduces hospitalization and leads to muscle hypertrophy in elderly hip surgery patients--a controlled, randomized study. Journal of the American Geriatrics Society 52, 2016-2022.

63. Suzuki, K. (2018). Cytokine Response to Exercise and Its Modulation. Antioxidants (Basel) 7, 17.

64. Thompson, L. V. (2002). Skeletal muscle adaptations with age, inactivity and therapeutic exercise. J Orthop Sports Phys Ther 32, 44-57.

65. Toien, T., Pedersen Haglo, H., Unhjem, R., Hoff, J. and Wang, E. (2018). Maximal strength training: the impact of eccentric overload. Journal of neurophysiology 120 , 2868-2876.

66. Travier, N., Velthuis, M. J., Bisschop, C. N. S., van den Buijs, B., Monninkhof, E. M., Backx, F., Los, M., Erdkamp, F., Bloemendal, H. J. and Rodenhuis, C. (2015). Effects of an 18-week exercise programme started early during breast cancer treatment: a randomised controlled trial. BMC medicine 13, 121.

67. Unhjem, R., Flemmen, G., Hoff, J. and Wang, E. (2016). Maximal strength training as physical rehabilitation for patients with substance use disorder; a randomized controlled trial. BMC Sports Sci Med Rehabil 8, 7-7.

68. Unhjem, R., Nygård, M., Hoff, J. and Wang, E.J.J.o.g.p.t. (2017). Functional Performance With Age: The Role of Long-Term Strength Training.

69. Van Waart, H., Stuiver, M. M., van Harten, W. H., Geleijn, E., Kieffer, J. M., Buffart, L. M., de Maaker-Berkhof, M., Boven, E., Schrama, J. and Geenen, M. M. (2015a). Effect of low-intensity physical activity and moderate-to high-intensity physical exercise during adjuvant chemotherapy on physical fitness, fatigue and 
chemotherapy completion rates: results of the PACES randomized clinical trial. J Clin Oncol 33, 1918-1927.

70. Van Waart, H., Stuiver, M. M., van Harten, W. H., Geleijn, E., Kieffer, J. M., Buffart, L. M., de Maaker-Berkhof, M., Boven, E., Schrama, J., Geenen, M. M., et al. (2015b). Effect of Low-Intensity Physical Activity and Moderate- to HighIntensity Physical Exercise During Adjuvant Chemotherapy on Physical Fitness, Fatigue and Chemotherapy Completion Rates: Results of the PACES Randomized Clinical Trial. J Clin Oncol 33, 1918-1927.

71. Wang, E., Helgerud, J., Loe, H., Indseth, K., Kaehler, N. and Hoff, J. (2010). Maximal strength training improves walking performance in peripheral arterial disease patients. Scand J Med Sci Sports 20, 764-770.

72. Wang, E., Nyberg, S. K., Hoff, J., Zhao, J., Leivseth, G., Tørhaug, T., Husby, O. S., Helgerud, J. and Richardson, R. S. (2017). Impact of maximal strength training on work efficiency and muscle fiber type in the elderly: Implications for physical function and fall prevention. Exp Gerontol 91, 64-71.

73. Wernbom, M., Augustsson, J. and Thomeé, R. (2007). The influence of frequency, intensity, volume and mode of strength training on whole muscle cross-sectional area in humans. Sports Med 37, 225-264.

74. Winters-Stone, K. M., Dobek, J., Nail, L. M., Bennett, J. A., Leo, M. C., Torgrimson-Ojerio, B., Luoh, S. W. and Schwartz, A. (2013). Impact + resistance training improves bone health and body composition in prematurely menopausal breast cancer survivors: a randomized controlled trial. Osteoporos Int 24, 1637- 1646. 


\section{Pateicības}

Vislielākā pateicība visām pētījuma dalībniecēm par uzticību, drosmi un godprātīgu pētījuma protokola pildīšanu.

L,oti pateicos darba vadītājam profesoram Eivindam Vangam (Eivind Wang) par ievadīšanu zinātnes pasaulē, par atbalstu un vērtīgajiem padomiem visa pētniecības procesa gaitā.

Liels paldies darba vadītājai asociētai profesorei Signei Tomsonei par atbalstu, veltīto laiku, palīdzību darba tapšanas gaitā.

Paldies darba konsultantam profesoram Jānim Eglītim par atbalstu un padomiem pētniecības laikā. Paldies par iespēju iegūt plašu redzesloku un prezentēt pētījuma rezultātus pasaules mērogā. Liels paldies Latvijas Onkologijias centra Krūts ķirurǵijas nodaḷas ārstiem un personālam.

Pateicos darba konsultantam profesoram Aivaram Vētram par iespējām īstenot pētījumu un vērtīgo atbalstu.

Liels paldies Dr. Marijai Petrovičai par nesavtīgo atbalstu un loti vērtīgiem padomiem darba tapšanā.

Vislielākais paldies manai ǵimenei un draugiem par ticību un neatsveramo atbalstu. 